\title{
Dynamic Performance and Anti-earthquake Analysis of Cable-stayed Arch Bridge
}

\author{
Shijie Wang ${ }^{1,2}$, Quansheng Sun ${ }^{1,}$, Hongshuai Gao ${ }^{1}$ \\ ${ }^{1}$ School of Civil Engineering, Northeast Forestry University, Harbin, China \\ ${ }^{2}$ School of Civil and Architectural Engineering, Heilongiiang Institute of Technology, Harbin, China \\ Email address: \\ twfxwsj@163.com (Shijie Wang), hrbsqs@126.com (Quansheng Sun),ghsphd@126.com (Hongshuai Gao) \\ ${ }^{*}$ Corresponding author
}

\section{To cite this article:}

Shijie Wang, Quansheng Sun, Hongshuai Gao. Dynamic Performance and Anti-earthquake Analysis of Cable-stayed Arch Bridge. Journal of Civil, Construction and Environmental Engineering. Vol. 5, No. 2, 2020, pp. 20-34. doi: 10.11648/j.jccee.20200502.12

Received: April 29, 2020; Accepted: May 11, 2020; Published: May 15, 2020

\begin{abstract}
The strength, stiffness, and stability check calculations and the effect of earthquakes should be considered in the design of cable-stayed arch bridges with collaborative systems. This study aims to investigate the dynamic performance and structural response of cable-stayed arch bridges under seismic action. The space analysis model is enhanced of the Xiang Feng River Bridge using finite element software Midas Civil, whose lower foundation considers the effects of piles and soil. Firstly the vibration period, vibration frequency, and modal characteristics are computed, thus the dynamic performance is summarized of the bridge. Then, a proper seismic wave is selected according to engineering conditions and in terms of three orthogonal directions: inputting the adjusted El Centro seismic wave, considering Rayleigh damping, and calculating via the Newmark method. Furthermore, a time-history response analysis under the action of one-dimensional and multidimensional earthquake is performed. Lastly, the results of the response analysis is compared and the behavior characteristics of arch bridge is summarized under seismic action. The results show that the transverse stability problem of bridges is prominent and should be the focus of antiearthquake fortification, the inclined cable tower of this bridge is not conducive to the earthquake resistance of the structure in comparison with the vertical cable tower. and the influence of horizontal and vertical earthquake actions should be considered in antiearthquake designs.
\end{abstract}

Keywords: Cable-stayed Arch Bridge, Dynamic Performance, Anti-earthquake Analysis, Parametric Analysis, Finite Element Analysis

\section{Introduction}

The major load-bearing parts of cable-stayed bridges are the cable stays, bridge towers, and stiffening beams [1]. In the early 20th century, cable-stayed bridges were developed rapidly due to the development, improvement, and production of high-strength, high-elastic-mold steel wires and its anchorage systems and the improvement of orthotropic steel bridge decks [2]. Currently, the cable-stayed bridge with largest span is the Russky Island Bridge built in 2012; as shown in Figure 1, its center span measures 1104 m, its longest stay cable is $483 \mathrm{~m}$, and the cantilever length of its main beam is $852 \mathrm{~m} \mathrm{[3]}$. However, with the increase of the span of cable-stayed bridges, the stability of the cantilever section of the stiffening beam before closing is difficult to guarantee. As the axial force in the stiffening beam is remarkable increased, the proportion of its own weight and the height of the tower are also increased, and the sag effect of the cable stay becomes evident.

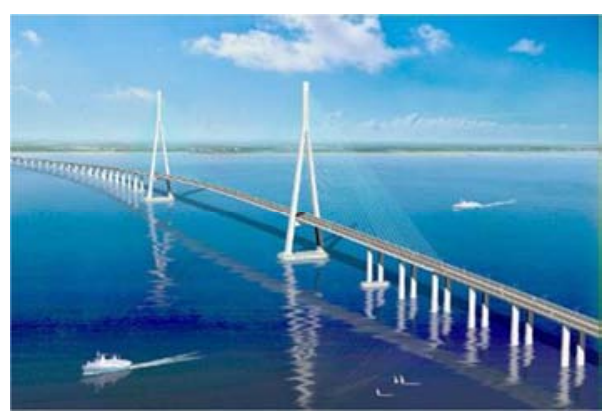

Figure 1. Russky Island Bridge. 


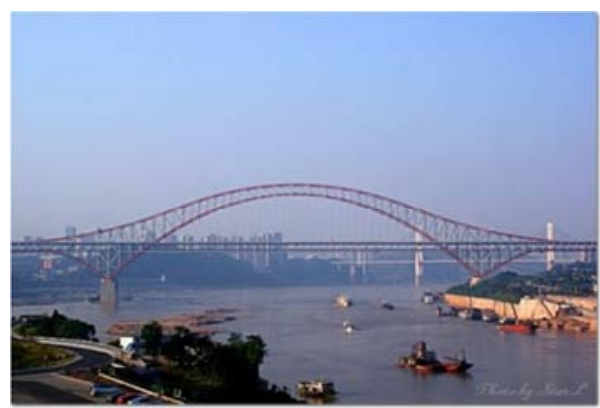

Figure 2. Chaotianmen Yangtze River Bridge.

As one of the basic forms of bridges, arch bridges have a history of more than 3,000 years [4]. With the continuous innovation of arch bridge building materials, construction technology, and design theory, arch bridges have achieved major breakthroughs in its span and structural form, from stone arch bridges in $\mathrm{BC}$ to concrete and simple steel arch bridges in the 19th century and then to truss and concrete-filled steel-tube arch bridges in the 20th century. In 2009, the Chaotianmen Yangtze River Bridge opened to traffic in China. It is the arch bridge with the largest main span in the world. Its mid-through continuous steel truss arch bridge structure is adopted in the main bridge $(190+552+190) \mathrm{m}$. The main span is installed with a buckle tower to assist the full extension arm from the arch to the beam, and the bridge is integrated in the span. The finished bridge is shown in Figure 2 [5]. With the increase of the span, the traditional arch bridge increased in its own weight, making cable construction difficult. Concrete-filled steel-tube arch bridges are prone to problems, such as corrosion and concrete hollowing in the tubes. Meanwhile, steel arch bridges are characterized by high cost, high maintenance, and stability problems.

Cable-stayed and arch bridges are long-span bridges that are commonly used worldwide. However, the further development of bridge spans is restricted by their respective shortcomings. As shown in Table 1, many cooperative systems of cable-stayed or arched bridges have been proposed by the engineering community due to the increasing demand for bridge aesthetics. These new types of bridges can maximize the respective advantages of cable-stayed and arch bridges, complementing each other's strengths and weaknesses. (1) The spanning capacity of the structure is increased, and its own rigidity is improved. (2) The shape is improved aesthetically. (3) The stability of the bridge structure is increased. (4) The safety of the bridge during the construction and operation phases is enhanced. (5) The height of the bridge tower is reduced. (6) The tension of the stay cable or suspension rod is decreased. (7) Coordination performance is great, and internal force distribution is uniform to reduce local stress. (8) Structural performance and economic benefits are enhanced.

Table 1. Detailed list of typical cable-stayed and arch bridges at home and abroad.

\begin{tabular}{|c|c|c|c|}
\hline Bridge name & $\begin{array}{l}\text { Bridge category with } \\
\text { collaborative system }\end{array}$ & Year & Overview \\
\hline Niagara Falls Bridge & Cable-stayed, suspended & 1855 & $\begin{array}{l}\text { The main span is } 232 \mathrm{~m} \text {. The main beam is a steel structure, which replaced cast } \\
\text { iron. The main tower is mainly composed of wood and limestone and is the } \\
\text { world's first railway suspension bridge. }\end{array}$ \\
\hline Albert Bridge & Cable-stayed, suspended & 1873 & $\begin{array}{l}\text { The span is }(35+122+35) \mathrm{m} \text {, and the width is } 12.5 \mathrm{~m} \text {. It is the oldest existing } \\
\text { cable-stayed suspension bridge in the world. }\end{array}$ \\
\hline Brooklyn Bridge & Cable-stayed, suspended & 1883 & $\begin{array}{l}\text { The span is }(286+486+286) \mathrm{m} \text {, the main beam is made of steel, and the main } \\
\text { tower is made of stone. }\end{array}$ \\
\hline $\begin{array}{l}\text { Messina Strait Bridge in } \\
\text { Italy }\end{array}$ & Cable-stayed, suspended & 1976 & $\begin{array}{l}\text { The span, which avoids the foundation construction in deep water, is }(960+ \\
3300+960) \mathrm{m} \text {. }\end{array}$ \\
\hline $\begin{array}{l}\text { Great Belt Bridge in } \\
\text { Denmark }\end{array}$ & Cable-stayed, suspended & 1978 & The span is $(400+1500+400) \mathrm{m}$. \\
\hline $\begin{array}{l}\text { Gaobingxi Bridge in } \\
\text { Taiwan }\end{array}$ & Cable-stayed, suspended & 1993 & $\begin{array}{l}\text { The span is }(120+130+920+130+120) \mathrm{m} \text {, and a suspension cable is used } \\
\text { within } 500 \mathrm{~m} \text { in the middle of the main span. }\end{array}$ \\
\hline Wujiang Bridge & Cable-stayed, suspended & 1997 & $\begin{array}{l}\text { The span is }(60+288+60) \mathrm{m} \text {. The entire bridge comprises a three-span } \\
\text { continuous concrete main beam, and the main beam is a concrete stiffening. }\end{array}$ \\
\hline Nagisa Bridge in Japan & Cable-stayed, suspended & 2002 & $\begin{array}{l}\text { The bridge span is } 110.15 \mathrm{~m} \text {. It is a cooperative system bridge composed of a } \\
\text { steel suspension bridge and a prestressed concrete cable-stayed bridge. }\end{array}$ \\
\hline $\begin{array}{l}\text { North Avenue Bridge in } \\
\text { the US }\end{array}$ & $\begin{array}{l}\text { Self-anchored cable-stayed, } \\
\text { suspended }\end{array}$ & 2007 & $\begin{array}{l}\text { The span is }(25.6+76.8+25.6) \mathrm{m} \text {. The main beam is made of } \\
\text { high-strength-reinforced concrete, and the main bridge tower is made of steel. }\end{array}$ \\
\hline Longcheng Bridge & $\begin{array}{l}\text { Self-anchored cable-stayed, } \\
\text { suspended }\end{array}$ & 2008 & $\begin{array}{l}\text { The span is }(72.2+113.8+30) \mathrm{m} \text {. Combined beams are adopted within } 87 \mathrm{~m} \text { in } \\
\text { the main span, and the rest of the parts are prestressed concrete beams. }\end{array}$ \\
\hline $\begin{array}{l}\text { Jianshe Bridge in } \\
\text { Zhuanghe }\end{array}$ & $\begin{array}{l}\text { Self-anchored cable-stayed, } \\
\text { suspended }\end{array}$ & 2008 & $\begin{array}{l}\text { The span is }(41.6+100+41.6) \mathrm{m} \text {. It is constructed by concrete main beams } \\
\text { whose height is } 2.17 \mathrm{~m} \text {. }\end{array}$ \\
\hline Longgang Bridge & $\begin{array}{l}\text { Self-anchored cable-stayed, } \\
\text { suspended }\end{array}$ & 2012 & $\begin{array}{l}\text { The span is }(25+90+2 \times 162.5+90+25) \mathrm{m} \text {. Steel-concrete beams are used } \\
\text { during the long section of the suspension cable for } 63 \mathrm{~m} \text {, and the rest are } \\
\text { prestressed concrete box beams. }\end{array}$ \\
\hline Changhong Bridge & $\begin{array}{l}\text { Self-anchored cable-stayed, } \\
\text { suspended }\end{array}$ & 2015 & $\begin{array}{l}\text { The span is }(2 \times 75+420+2 \times 75) \mathrm{m} \text {. It is a double-tower, self-anchored, } \\
\text { cable-stayed suspended bridge, and the main beam is steel box girder. }\end{array}$ \\
\hline Dalian Bay Bridge & $\begin{array}{l}\text { Self-anchored cable-stayed, } \\
\text { suspended }\end{array}$ & & $\begin{array}{l}\text { The span is }(263+800+263) \mathrm{m} \text {. The main beams are steel and concrete box } \\
\text { beams. }\end{array}$ \\
\hline $\begin{array}{l}\text { Bay Bridge in Jinzhou, } \\
\text { Dalian }\end{array}$ & $\begin{array}{l}\text { Self-anchored cable-stayed, } \\
\text { suspended }\end{array}$ & & $\begin{array}{l}\text { The main span is } 400 \mathrm{~m} \text {. The main beam of the suspension cable part is made of } \\
\text { steel box beams, whereas the cable-stayed part is made of concrete box beams. }\end{array}$ \\
\hline
\end{tabular}




\begin{tabular}{|c|c|c|c|}
\hline Bridge name & $\begin{array}{l}\text { Bridge category with } \\
\text { collaborative system }\end{array}$ & Year & Overview \\
\hline $\begin{array}{l}\text { Bay Bridge in Xiaoping } \\
\text { Island, Dalian }\end{array}$ & $\begin{array}{l}\text { Self-anchored cable-stayed, } \\
\text { suspended }\end{array}$ & & $\begin{array}{l}\text { The main span is } 350 \mathrm{~m} \text {. The main beam of the suspension cable part is made of } \\
\text { steel box beams, whereas the cable-stayed part is made of concrete box beams. }\end{array}$ \\
\hline $\begin{array}{l}\text { E'dong Yangtze River } \\
\text { Bridge }\end{array}$ & $\begin{array}{l}\text { Self-anchored cable-stayed, } \\
\text { suspended }\end{array}$ & & $\begin{array}{l}\text { The main span is } 1100 \mathrm{~m} \text {. The main beam of the suspension cable part is made } \\
\text { of steel box beams, whereas the cable-stayed part is made of concrete box } \\
\text { beams. }\end{array}$ \\
\hline Putrajaya Bridge & Cable-stayed, arch & 2002 & $\begin{array}{l}\text { The main span is } 300 \mathrm{~m} \text {. It consists of two arched ribs at the top and a typical } \\
\text { double-tower cable-stayed bridge. }\end{array}$ \\
\hline Liancheng Bridge & Cable-stayed, arch & 2006 & $\begin{array}{l}\text { It is a cable-stayed taut-tied parallel arch bridge with span of }(120+400+120) \\
m \text {. }\end{array}$ \\
\hline Xiangfeng River Bridge & Cable-stayed, arch & 2016 & $\begin{array}{l}\text { The span is }(40+90.5) \mathrm{m} \text {. The bridge is composed of a cable-stayed bridge } \\
\text { without a backstay and a special-shaped arch bridge. }\end{array}$ \\
\hline $\begin{array}{l}\text { Tongling Bridge in } \\
\text { Anhui }\end{array}$ & Cable-stayed, rigid framework & 1991 & $\begin{array}{l}\text { The span is }(80+90+190+432+190+90+80) \mathrm{m} \text {. It is composed of a } \\
\text { cable-stayed bridge with double-tower double-cable prestressed concrete and a } \\
\text { side span with a continuous T-shaped rigid framework. }\end{array}$ \\
\hline Jinma Bridge & Cable-stayed, rigid framework & 1999 & $\begin{array}{l}\text { The span is }(60+283+283+60) \mathrm{m} \text {. It is a concrete single tower cable-stayed } \\
\text { structure with the world's longest span. }\end{array}$ \\
\hline Mengwu Bridge in Japan & Main-sub arch & 2002 & $\begin{array}{l}\text { The span is }(65+280+65) \mathrm{m} \text {. It has double-arch ribs with unparalleled upper } \\
\text { and lower chords. }\end{array}$ \\
\hline Foshan Dongping Bridge & Main-sub arch & 2006 & The span is $(43.4+95.5+300+95.5+43.5) \mathrm{m}$, with three arch ribs. \\
\hline $\begin{array}{l}\text { Taohuayu Yellow River } \\
\text { Bridge in Zhengzhou }\end{array}$ & Self-anchored, suspended & 2009 & $\begin{array}{l}\text { The span is }(170.125+406+170.125) \mathrm{m} \text {. A double-tower three-span } \\
\text { self-anchored suspension bridge is above the bridge deck, and a three-span } \\
\text { taut-tied arch structure is adopted below the bridge deck. }\end{array}$ \\
\hline $\begin{array}{l}\text { Columbia Bridge in the } \\
\text { US }\end{array}$ & Cable-stayed, continuous beam & 1978 & $\begin{array}{l}\text { The span is }(38+124+299+124+3 \times 45+38) \mathrm{m} \text {. It consists of a } \\
\text { cable-stayed bridge with continuous beams on both sides. }\end{array}$ \\
\hline East Huntington Bridge & Cable-stayed, continuous beam & 1985 & $\begin{array}{l}\text { The main beam is structured by a double main rib section. The bridge tower is a } \\
\text { single tower with a height of } 2.27 \mathrm{~m}\end{array}$ \\
\hline $\begin{array}{l}\text { Yellow River Bridge in } \\
\text { Jinan }\end{array}$ & Cable-stayed, continuous beam & 1982 & $\begin{array}{l}\text { The span is }(40+94+220+94+20) \mathrm{m} \text {. It is a continuous prestressed concrete } \\
\text { double-tower cable-stayed bridge. }\end{array}$ \\
\hline Bayi Bridge in Nanchang & Cable-stayed, continuous beam & 1997 & $\begin{array}{l}\text { The span is }(50+2 \times 160+3 \times 50+3 \times 50+2 \times 160+50) \mathrm{m} \text {. It is a cable-stayed } \\
\text { bridge with continuous beams on both sides. }\end{array}$ \\
\hline $\begin{array}{l}\text { Third bridge in the } \\
\text { Qiantang River }\end{array}$ & Cable-stayed, continuous beam & 1997 & $\begin{array}{l}\text { The span is }(72+80+168+168+80+72) \mathrm{m} \text {. It consists of a single } \\
\text { five-chamber box beam whose height is } 3.5 \mathrm{~m} \text {. }\end{array}$ \\
\hline Zhaobaoshan Bridge & Cable-stayed, continuous beam & 2001 & $\begin{array}{l}\text { The span is }(74.5+258+102+83+49.5) \mathrm{m} \text {. The main tower is } 148.4 \mathrm{~m} \text { high, } \\
\text { and the asymmetric prestressed concrete cable-stayed bridge has a single tower } \\
\text { and a double-cable plane. }\end{array}$ \\
\hline East Wellington Bridge & Cable-stayed, continuous beam & 2008 & The main span is $67 \mathrm{~m}$, and the main tower is made of stone. \\
\hline Dengjiayao Bridge & Beam, arch & 2012 & $\begin{array}{l}\text { The main span is } 158 \mathrm{~m} \text {. A half-through arch bridge and a simply supported } \\
\text { beam bridge are adopted. }\end{array}$ \\
\hline Obere Argen Bridge & $\begin{array}{l}\text { Cable-stayed, deck cable } \\
\text { suspension }\end{array}$ & 1985 & $\begin{array}{l}\text { The span is }(42+5 \times 86+250) \mathrm{m} \text {. The main beam is made of steel, and the main } \\
\text { tower is } 55 \mathrm{~m} \text { high. }\end{array}$ \\
\hline Miho Museum Bridge & $\begin{array}{l}\text { Cable-stayed, deck cable } \\
\text { suspension }\end{array}$ & 1997 & $\begin{array}{l}\text { The main span is } 120 \mathrm{~m} \text {. The main beam is made of steel truss, and the cable on } \\
\text { one side is anchored on the concrete tunnel. }\end{array}$ \\
\hline
\end{tabular}

Although cable-stayed or arched bridges appeared early, their development has been slow. People remain skeptical about bridges with collaborative systems due to the complex mechanical characteristics of its structure, the immature related design theory, the imperfect construction management, and some bridge accidents on the cooperative systems that have been completed and opened to traffic. However, the development of bridges in related collaboration systems has played a crucial role in achieving breakthroughs for bridges [6]. Cable-stayed arch bridges are a new type of bridge with a composite system that emerged at the beginning of this century. Theoretical studies on cable-stayed arch bridges are still in its infancy. Pascal Klein introduced the structure and construction process of Malaysia's Jambatan God Shawjala Bridge [7] in detail. With the Liancheng Bridge as the background, Yang Xiangzhan, H. J. Kang, Luo Shidong, Tu Yangzhi, Jiang Hua, Wang Meizhi, etc. performed analysis and verification of seismic performance, dynamic performance experiment analysis, local stress analysis, cable force optimization analysis, parameter analysis, and temperature gradient effect analysis of the box girder section of cable-stayed arch bridges [8-13]. Sun Quansheng et al. analyzed the static and construction stress characteristics of the Xiangfeng River Bridge under construction in Dalian [14]. In this study, the dynamic characteristics, the structural response under seismic action, and the seismic measures of the Xiangfeng River Bridge were investigated. The results of this study can provide a reference for the seismic design of similar bridges and promote the development of cable-stayed arch bridges. With the development of society and economy, the increasing demand for bridge aesthetics will promote the construction of collaborative bridges with beautiful and unique shapes, good structural performance, and considerable economic benefits.

\section{Project Background}

The Xiangfeng River Bridge, which is located in the 
Wolong Bay Business District of Dalian, is a bridge that crosses the Xiangfeng River under the East Huanghai Road and alleviates traffic stress and styling.

This bridge, which has two spans measuring $40 \mathrm{~m}+90$ $\mathrm{m}=130 \mathrm{~m}$, features a cable-stayed bridge without backstays and a special-shaped arch bridge. The bridge deck is a variable-width structure with a full deck width of 39.0-43.0 $\mathrm{m}$. The main beam is a PC cast-in-place box beam. The height of the beam in the middle span is $2.7 \mathrm{~m}$ and is changed to $3.8 \mathrm{~m}$ within a range of $21 \mathrm{~m}$ on the left and right sides of the pier top. The tower column is a reinforced concrete structure, with a horizontal inclination angle of $56^{\circ}$, and the tower height above the bridge deck is $59.5 \mathrm{~m}$. The bottom of the tower is consolidated with the main beam, arch foot, and main pier. The cable is a finished cable; that is, the cable system is formed by the entire strand extrusion of the steel, with a total of eight cables that are arranged in $8.5 \mathrm{~m}$ intervals. The arch rib is a special-shaped arch with a steel box structure and divided into left and right pieces. The steel box is hollow, and the concrete is poured only near the arch foot. The rise-span ratio of the arch axis is $1 / 3$, in which the rise height is $28 \mathrm{~m}$, and the span is $84 \mathrm{~m}$, showing a quadratic parabola and straight line. The main pier is a wall pier, which is consolidated with the main beam, tower, and arch. The auxiliary pier is a rectangular column pier, and the foundation is a pile cap foundation. The design reference period of the bridge structure is 100 years, and the seismic fortification intensity is VII. The overall layout of the bridge is shown in Figure 3.

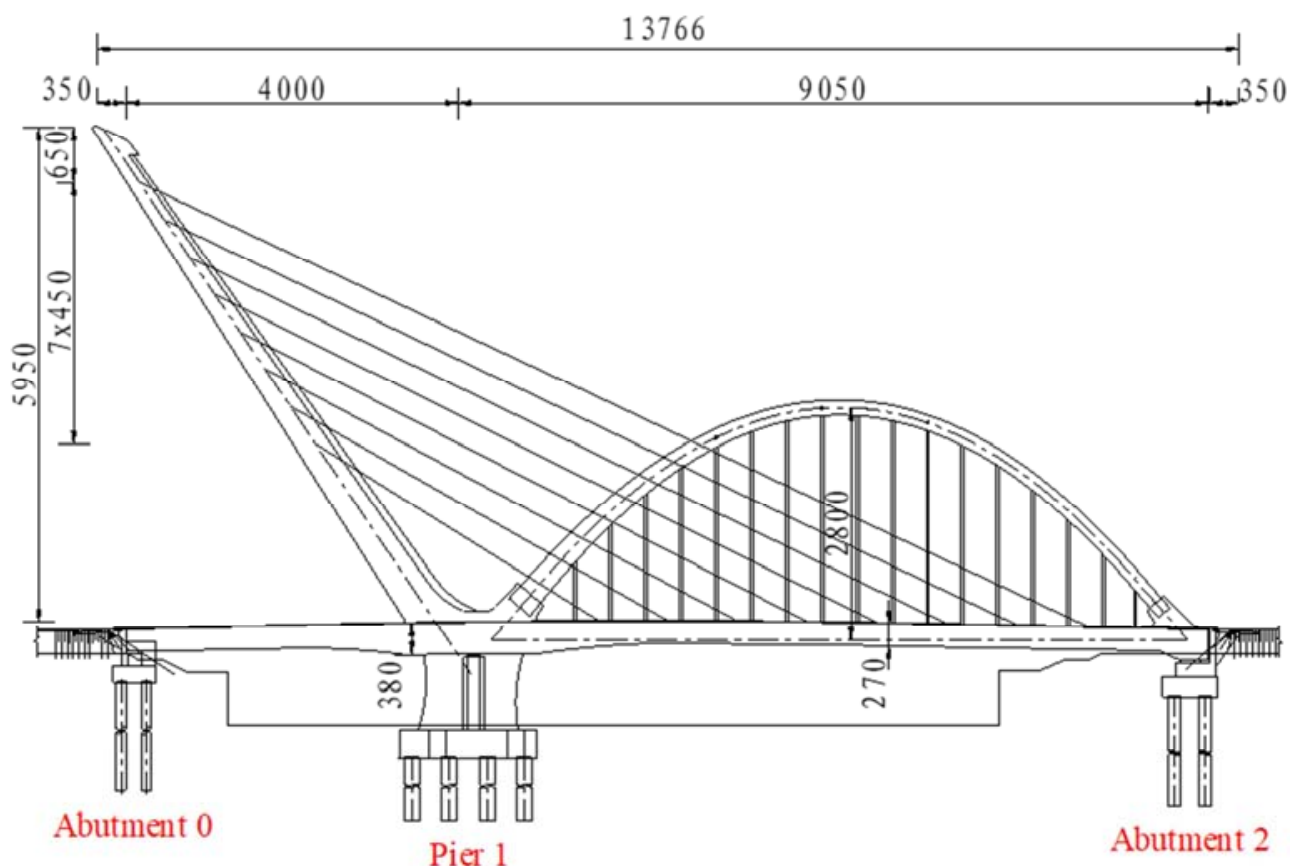

Figure 3. Overall layout of the entire bridge $(\mathrm{cm})$.

\section{Theoretical Calculation and Analysis Method}

The problem of the dynamic response of a multidegree of freedom system can be concluded mathematically as the initial value problem of a second-order ordinary differential equation system, as follows $[15,16]$ :

$$
\begin{gathered}
M \dot{q}(t)+C(t) \dot{q}(t)+K(t) q(t)=P(t) \\
\dot{q}(0)=\dot{q}_{0} \quad q(t)=q_{0} .
\end{gathered}
$$

Equations (1) and (2) show that the damping and stiffness matrices of the structure are time functions. The structure takes different values for different stress statuses, which can be solved using the step-by-step integration method. The equation of motion via the step-by-step integration method is solved as follows: First, the duration of the seismic action is discretized into $t_{1}, t_{2} \ldots t_{\mathrm{n}}$ finite time nodes. Equation (1) can be satisfied at each discrete time node; that is, the value of the structural displacement, velocity, and acceleration at each time node under seismic action can be solved. Assuming the structure's seismic response, such as displacement, velocity, acceleration, meets a certain relationship within the time period $\Delta t, \Delta t$ must be selected to ensure the accuracy and stability of the analysis calculation.

\section{Establishment of Finite Element Model}

In this study, the finite element analysis software Midas Civil 2015 is used to analyze the structure of the bridge. The space beam grillage method is used to establish the finite element analysis model of full bridges in proportion to the actual position of each member. The units are divided in accordance with the principle of satisfying calculation 
accuracy and calculation convenience. In the model, the truss unit is used for the boom and the stay cable, and the elastic modulus of the truss unit is modified in accordance with actual material parameters. The beam units are used for the main beam, cable tower, arch ribs, and lower components. The rigid connection is used for the connection of the boom and the cable stay unit to the main beam, cable tower, or arch rib unit.

The grillage system of the main beam is composed of different types of longitudinal beams and cross beams. The main span box girder is divided into three longitudinal beams in accordance with the cross section, and the side span is divided into seven longitudinal beams. Virtual longitudinal beams are provided on both sides of the bridge deck for the convenience of loading; beams are set in accordance with actual beam and diaphragm positions, and a certain number of virtual beams are set for the side span.

The top of the main pier is consolidated with the main beam, skewbacks, and bottom of the tower. Moreover, the elastic connection between the top of the auxiliary pier and the crossbeam is used to simulate the support in accordance with the stiffness equivalent method. In accordance with the engineering geological conditions, the equivalent soil spring stiffness is calculated in different depths, and the elastic support of the nodes is set at each element node of the base components to simulate the boundary conditions.

According to the above modeling principles, the full bridge structure is divided into 2619 units. The finite element model of the space is shown in Figure 4.

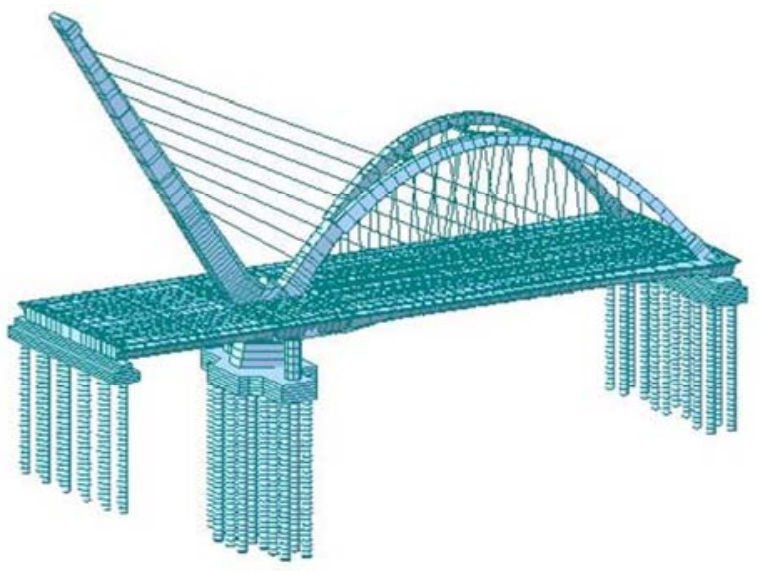

Figure 4. Finite element model.

On the basis of the basic theory of structural dynamic characteristics, a modal analysis of the Xiangfeng River Bridge is conducted with the assist of finite element software. The first 50 orders of natural frequency, period, and vibration shape are calculated using the subspace iteration method. The characteristics of the vibration mode is described, and a period change graph of the natural vibration is drawn to master the basic dynamic performance of the Xiangfeng River Bridge.
Table 2. Natural frequency and vibration characteristics of the bridge.

\begin{tabular}{|c|c|c|}
\hline Modal No. & Frequency $(\mathrm{Hz})$ & Modal No. \\
\hline 1 & 0.5038 & 1.9849 \\
\hline 2 & 0.9051 & 1.1049 \\
\hline 3 & 1.5681 & 0.6377 \\
\hline 4 & 1.7357 & 0.5761 \\
\hline 5 & 1.8124 & 0.5517 \\
\hline 6 & 2.0129 & 0.4968 \\
\hline 7 & 2.1645 & 0.4620 \\
\hline 8 & 2.8733 & 0.3480 \\
\hline 9 & 2.9047 & 0.3443 \\
\hline 10 & 3.0736 & 0.3254 \\
\hline 11 & 3.4564 & 0.2893 \\
\hline 12 & 3.8830 & 0.2575 \\
\hline 13 & 4.4944 & 0.2225 \\
\hline 14 & 4.5288 & 0.2208 \\
\hline 15 & 4.6481 & 0.2151 \\
\hline 16 & 4.9223 & 0.2032 \\
\hline 17 & 5.3718 & 0.1862 \\
\hline 18 & 5.3819 & 0.1858 \\
\hline 19 & 5.7088 & 0.1752 \\
\hline 20 & 6.2276 & 0.1606 \\
\hline 21 & 6.2530 & 0.1599 \\
\hline 22 & 6.4530 & 0.1550 \\
\hline 23 & 6.6242 & 0.1510 \\
\hline 24 & 6.7700 & 0.1477 \\
\hline 25 & 6.9405 & 0.1441 \\
\hline 26 & 7.4381 & 0.1344 \\
\hline 27 & 7.7328 & 0.1293 \\
\hline 28 & 7.7817 & 0.1285 \\
\hline 29 & 8.1742 & 0.1223 \\
\hline 30 & 8.3792 & 0.1193 \\
\hline 31 & 8.5524 & 0.1169 \\
\hline 32 & 8.7223 & 0.1146 \\
\hline 33 & 8.8661 & 0.1128 \\
\hline 34 & 8.9679 & 0.1115 \\
\hline 35 & 9.2877 & 0.1077 \\
\hline 36 & 9.3770 & 0.1066 \\
\hline 37 & 9.8154 & 0.1019 \\
\hline 38 & 9.9110 & 0.1009 \\
\hline 39 & 10.2786 & 0.0973 \\
\hline 40 & 10.6985 & 0.0935 \\
\hline 41 & 11.0006 & 0.0909 \\
\hline 42 & 11.2832 & 0.0886 \\
\hline 43 & 11.6206 & 0.0861 \\
\hline 44 & 11.9005 & 0.0840 \\
\hline 45 & 12.0472 & 0.0830 \\
\hline 46 & 12.3109 & 0.0812 \\
\hline 47 & 12.4407 & 0.0804 \\
\hline 48 & 12.4990 & 0.0800 \\
\hline 49 & 12.6373 & 0.0791 \\
\hline 50 & 12.7436 & 0.0785 \\
\hline
\end{tabular}




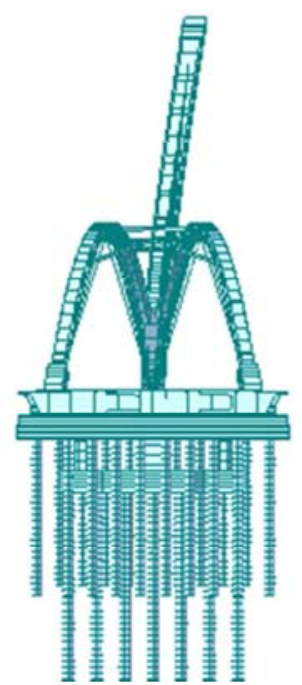

l) First-order modal shape

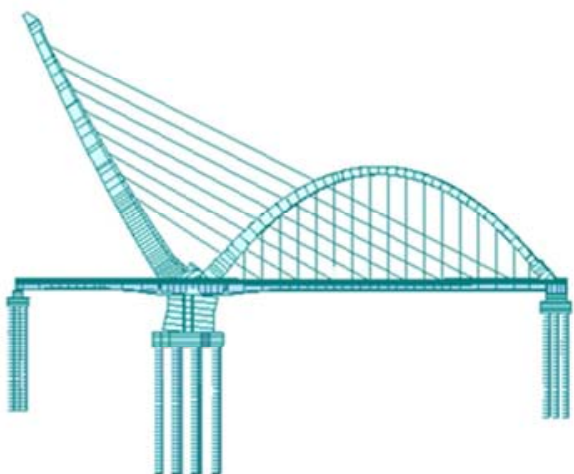

(b) Second-order modal shape

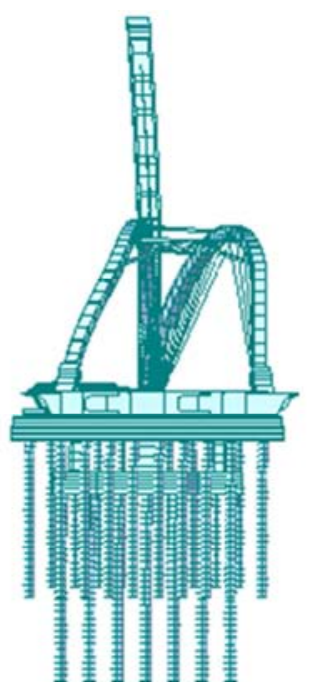

(c) Third-order modal shape

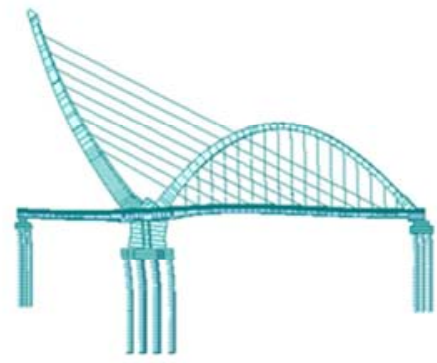

(d) Fourth-order modal shape

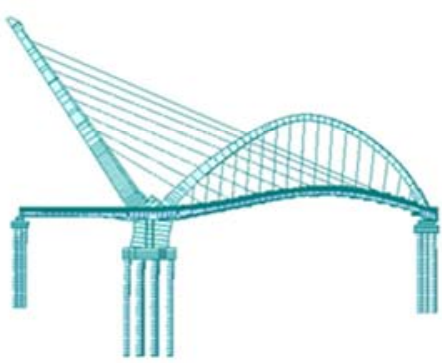

(e) Fifth-order modal shape

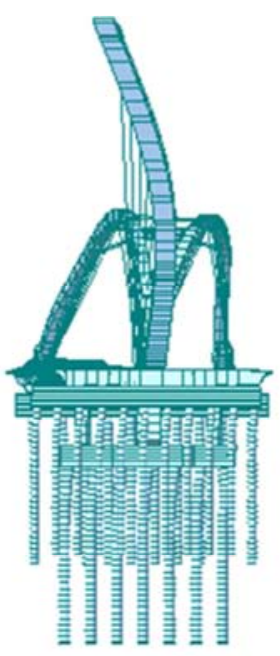

(f) Sixth-order modal shape

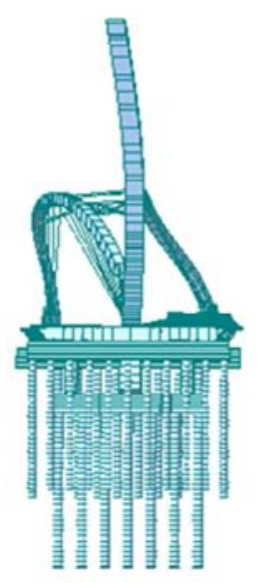

'g) Seventh-order modal shape

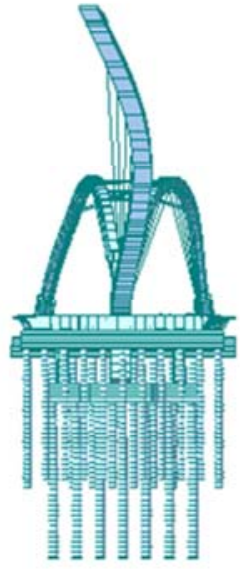

(h) Eighth-order modal shape

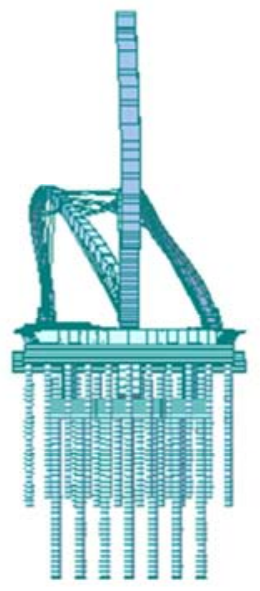

(i) Ninth-order modal shape

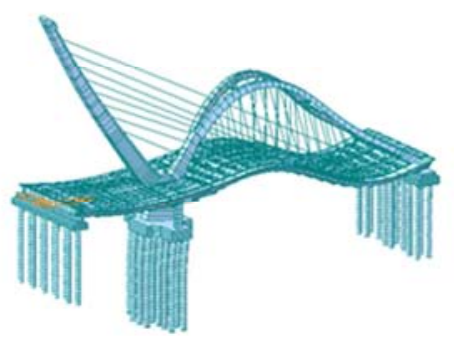

(j) Tenth-order modal shape

Figure 5. First tenth-order modal shapes of the Xiangfeng River Bridge. 
Table 3. Main vibration features of the first tenth-order modal shapes of the Xiangfeng River Bridge.

\begin{tabular}{ll}
\hline Modal No. & Main vibration features \\
\hline 1 & First-order transverse bending of the cable tower (W) \\
2 & Slightly longitudinal buckling of the cable tower and slightly longitudinal drift of the bridge deck (N, Z) \\
3 & First-order torsion of the main beam and reverse bending of the cable tower and arch rib (W, SG-F, WN) \\
4 & Slightly vertical bending of the main beam, longitudinal buckling of the cable tower, and slightly longitudinal drift of the bridge deck (N, Z) \\
5 & First-order symmetrical vertical bending of the main beam and slightly longitudinal buckling of the pier foundation (N, Z-D) \\
6 & Torsional deflection of the main beam, S-shaped transverse bending of the cable tower, and transverse bending of the arch rib (W, SG-F, WN) \\
7 & Torsional deflection of the main beam, transverse bending of the cable tower, and torsional deflection of the arch rib (W, SG-T, WN) \\
8 & S-shaped transverse bending of the cable tower and slight bending of the arch rib (W, SG-F) \\
9 & S-shaped transverse bending of the cable tower and slight twisting and bending of the arch rib (W, WN) \\
10 & First-order antisymmetric vertical bending of the main beam and longitudinal buckling of the pier foundation (N, Z-F, Z) \\
\hline
\end{tabular}

\section{Time History Analysis of Seismic Response}

\subsection{Seismic Wave Selection and Input}

In seismic engineering, seismic waves are considered elastic waves; that is, particles vibrate in the form of waves when an earthquake occurs and propagate in different directions along the epicenter. Seismic waves are mainly divided into surface and body waves due to different propagation media. The seismic waves can be reflected at the junction of different soil layers in the inhomogeneous medium to meet the continuous deformation condition and stress balance at the interface. Therefore, surface waves are formed. In an ideal infinite homogeneous medium, seismic waves are not reflected; thus, body waves are formed. In accordance with the rotation or distortion, surface waves can be divided into $\mathrm{P}$ waves (longitudinal waves) and $\mathrm{S}$ waves (transverse waves. [17, 18]

The soil of the bridge site is type II site soil, that is, medium and soft site soil. The spectral characteristic range of the input seismic wave is determined in accordance with the period of the site characteristic, and the El Centro wave is selected as the input seismic wave for structural time history analysis. Afterward, the maximum value of acceleration response spectrum $S_{\max }$ is designed in accordance with the E2 earthquake action levels to determine the peak horizontal acceleration PGA.

$$
P G A=\frac{S_{\max }}{2.25}=C_{i} C_{s} C_{d} A=1.7 \times 1.0 \times 1.0 \times 0.15 g=0.255 g
$$

In accordance with the PGA, the adjustment coefficient of the peak value of the input seismic wave is calculated. Five to 10 times of the basic structure period is selected because the duration of the seismic wave in the calculation is $20 \mathrm{~s}$. The adjustment data of the El Centro wave are shown in Table 4 .

Table 4. Peak displacement response of the main section under E2 earthquake action.

\begin{tabular}{lll}
\hline Seismic wave name & Input direction & Adjustment coefficient \\
\hline El Centro Site, 180 Deg & Directions along the bridge (X) & 1.1905 \\
El Centro Site, 270 Deg & Transverse direction (Y) & 0.7145 \\
El Centro Site, Vertical & Vertical direction (Z) & $1.0332(\times 0.65)$ \\
El Centro Site, 180 Deg & Directions along the bridge (X) & 1.1905 \\
\hline
\end{tabular}

The input seismic waves in all directions after adjustment are shown in Figure 6.

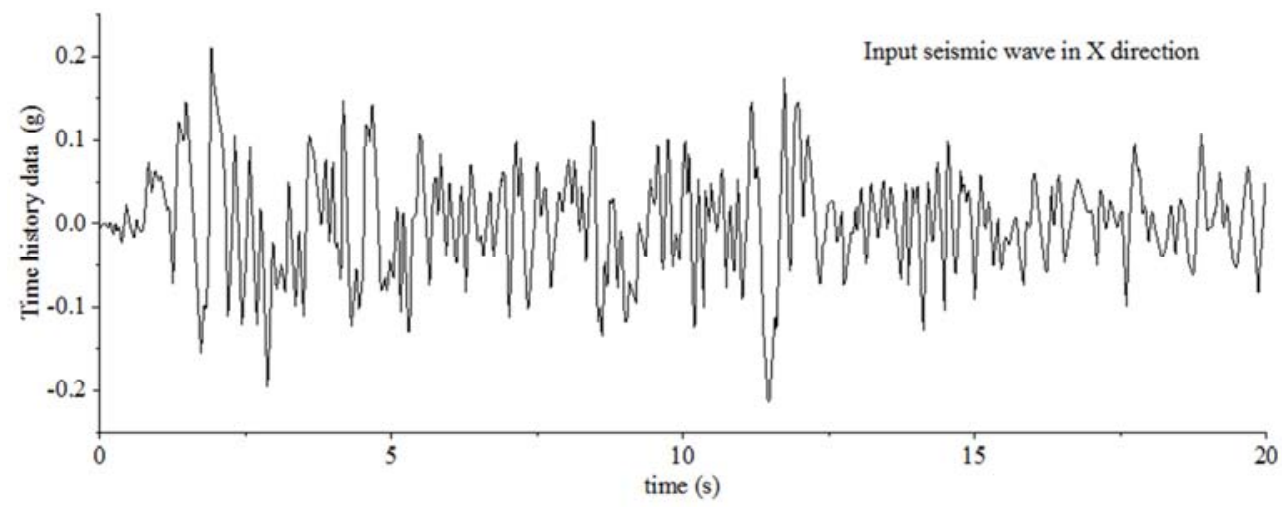


(a) Input seismic waves in the direction along the bridge

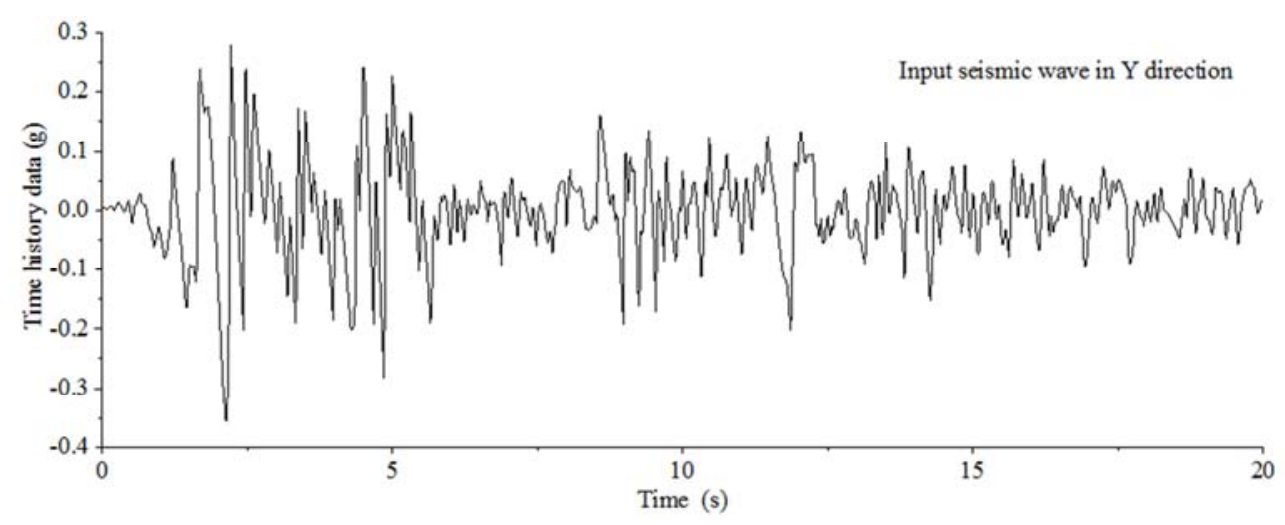

(b) Input seismic waves in the transverse direction

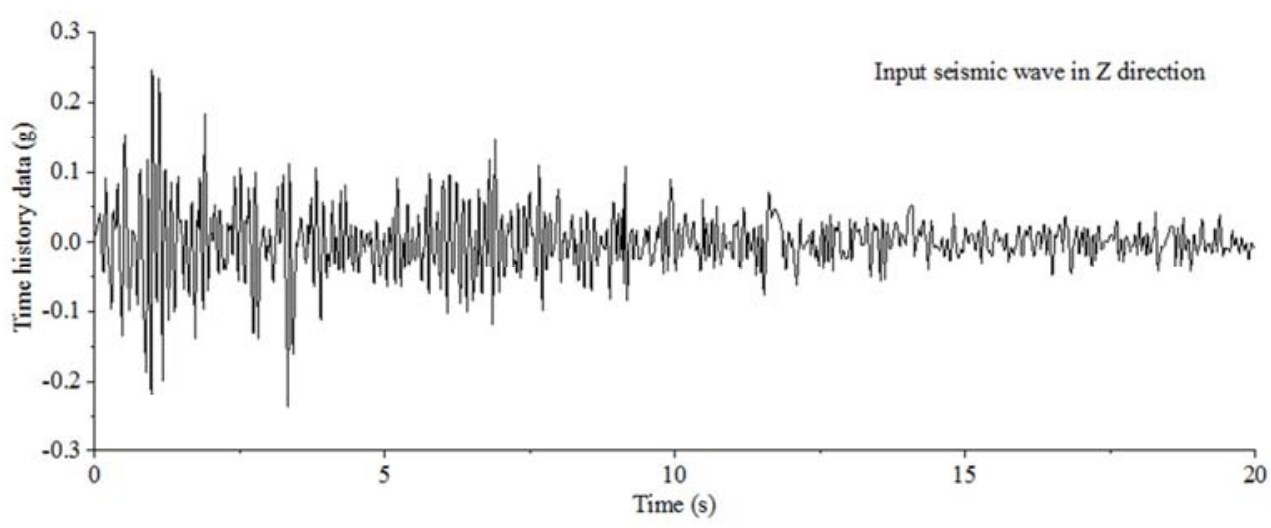

(c) Input seismic waves in the vertical direction

Figure 6. Analysis of seismic waves by inputting time history in each direction.

\subsection{Time-history Response Under One-dimensional Earthquake Conditions}

The stiffness of the bridge structure varies in all directions, and responses under the action of single- and multi-direction earthquakes differ. First, the time-history response at each control point of the structure under the action of a one-dimensional earthquake is analyzed. By comparing the response spectrum analysis, six displacement response control points are selected for time-history analysis. The points are as follows: main tower top (P1), arch top (P2), main pier top (P3), 2\# midspan (P4), 2\# span beam end (P5), and 2\# pier top (P6). The calculation results are shown in Figures 7-9.

Three orthogonal directions are separately considered in the one-dimensional seismic wave input, which is divided into three working conditions, namely,

Working condition 1: input in the transverse direction,

Working condition 2: input in the direction along the bridge,

Working condition 3: input in the vertical direction.

Analysis of the above figures reveals the following:

1) Under working condition 1, the displacement response value in the longitudinal and vertical structures is small when responses to the displacement in the transverse direction occur in the structure.
2) Under working conditions 2 and 3, the deformation of the structure leads to vertical (or along the bridge) displacement when the structure is displaced along the bridge (or vertically). Therefore, the displacement response of the structure along the bridge direction and the vertical direction occurs, and a structural displacement response in the transverse direction is slight.

3) With circumstances (1) and (2) combined, the displacement response of the structure mainly occurs under seismic action in the transverse direction, and the structural deformation is small. Structural deformation occurs in addition to the displacement response and structural deformation under seismic action in the direction along the bridge and the vertical direction. In consideration of the ductile design concept and the principle of energy dissipation, the seismic resistance of the transverse bridge is weak.

\subsection{Time-history Response Under Multidimensional Earthquake Conditions}

Results of the time-history response of the structure under multidimensional earthquake conditions at each control point is shown in Figures 10-11. Horizontal seismic input and that from three orthogonal directions are simultaneously 
considered in the multidimensional seismic wave input, which is divided into two working conditions, namely,

working condition 4: input in the transverse direction +

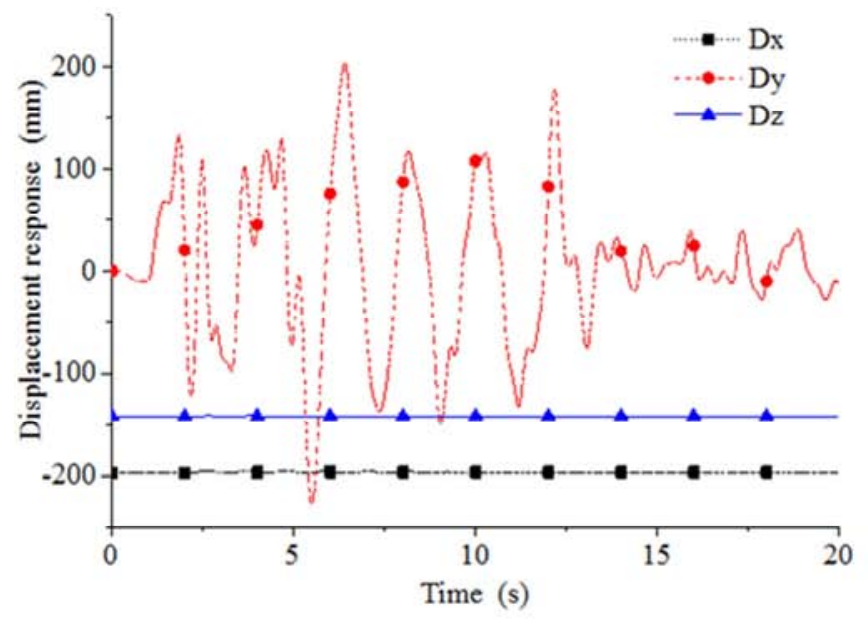

(a) P1

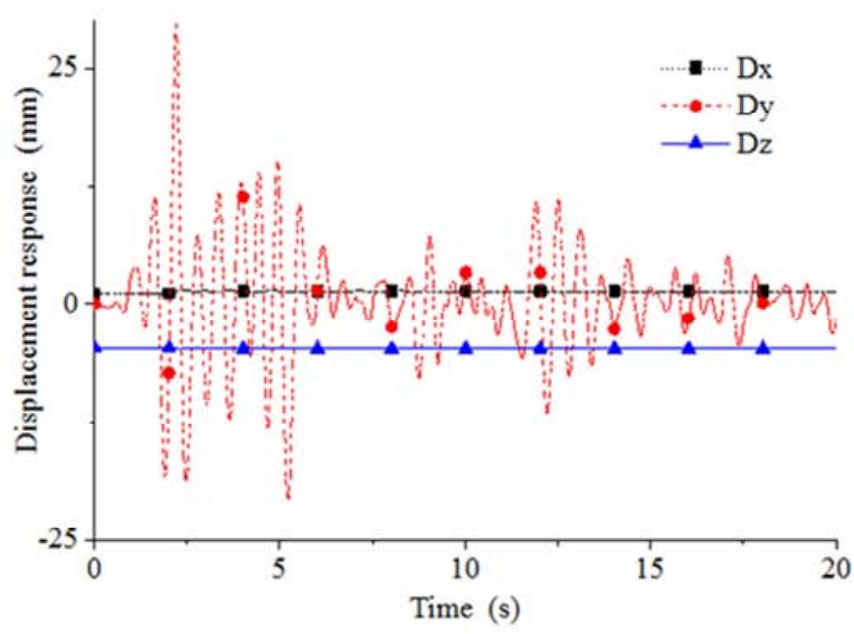

(c) P3

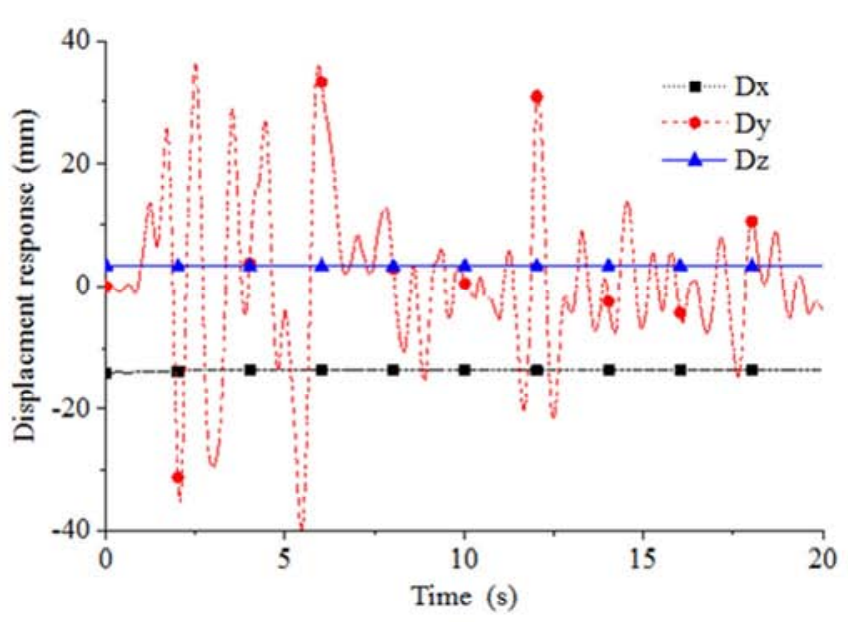

(e) P5 direction along the bridge and

working condition 5: input in the transverse direction + direction along the bridge + vertical direction.

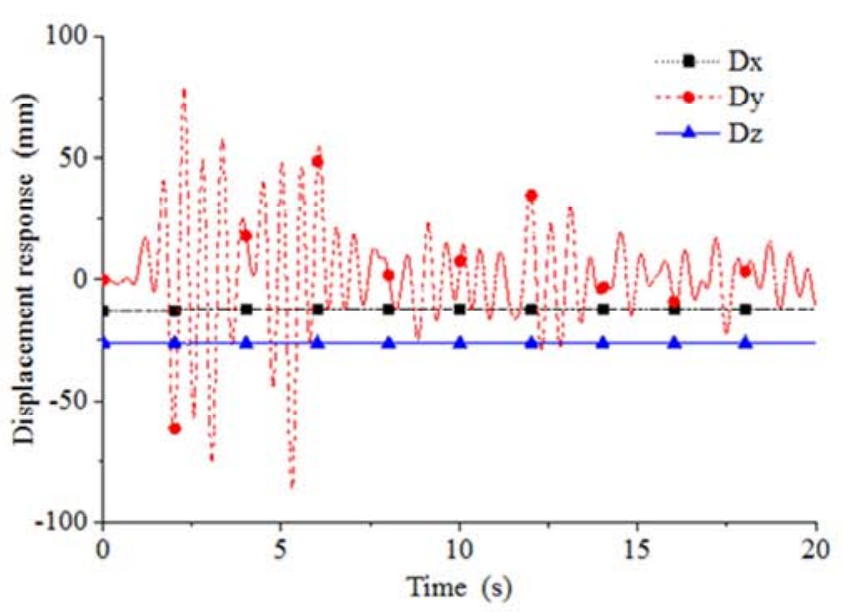

(b) P2

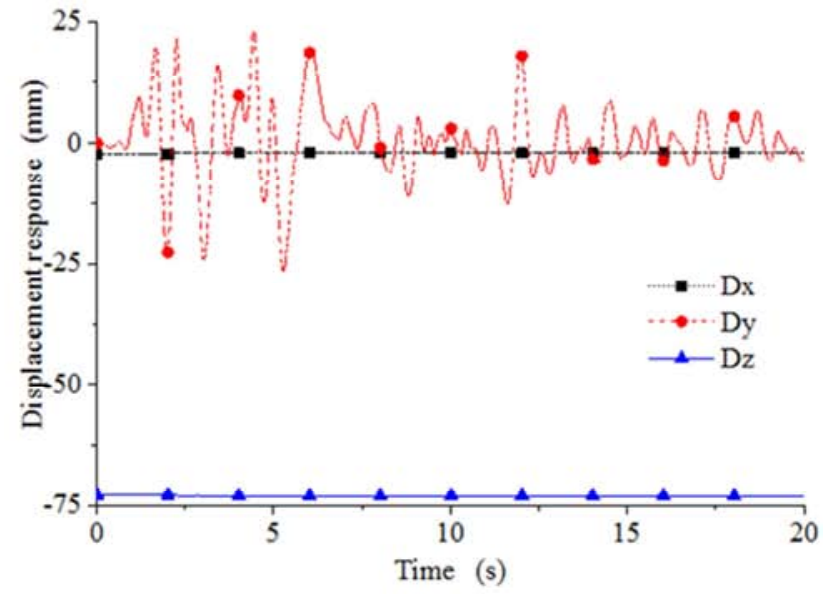

(d) P4

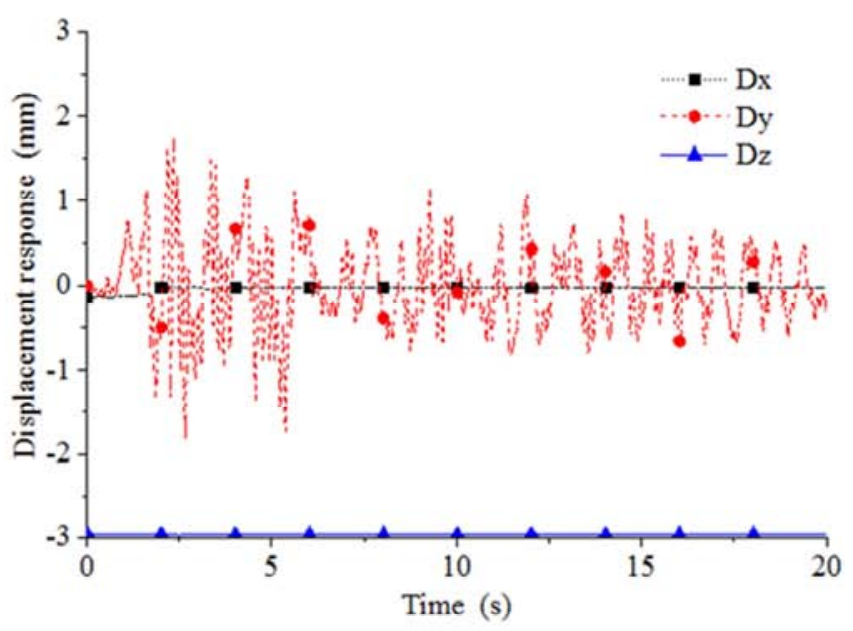

(f) P6

Figure 7. Displacement response results of each control point under working condition 1. 


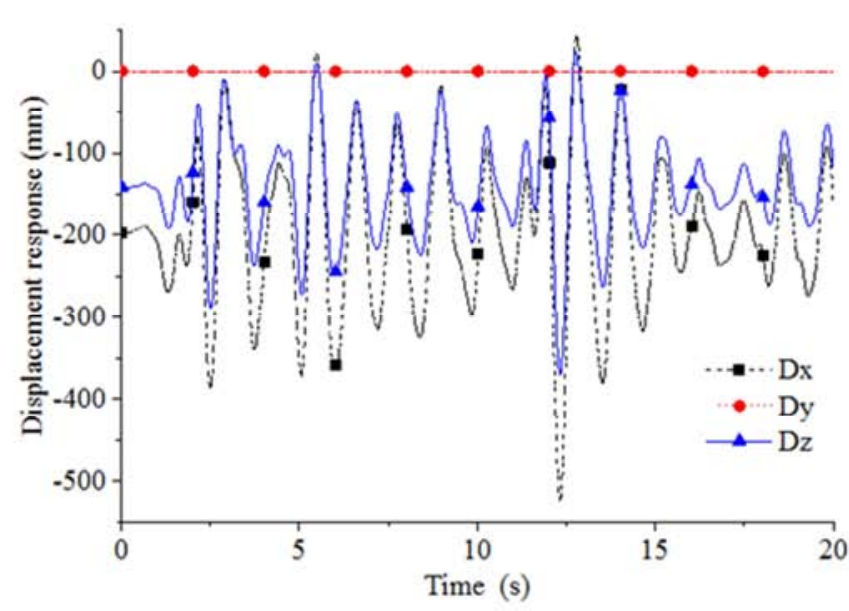

(a) P1

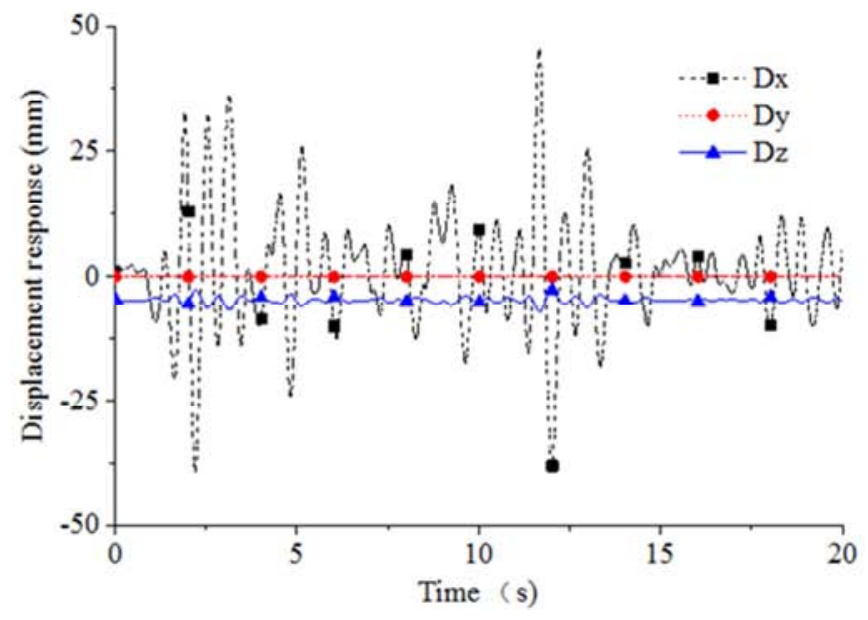

(c) P3

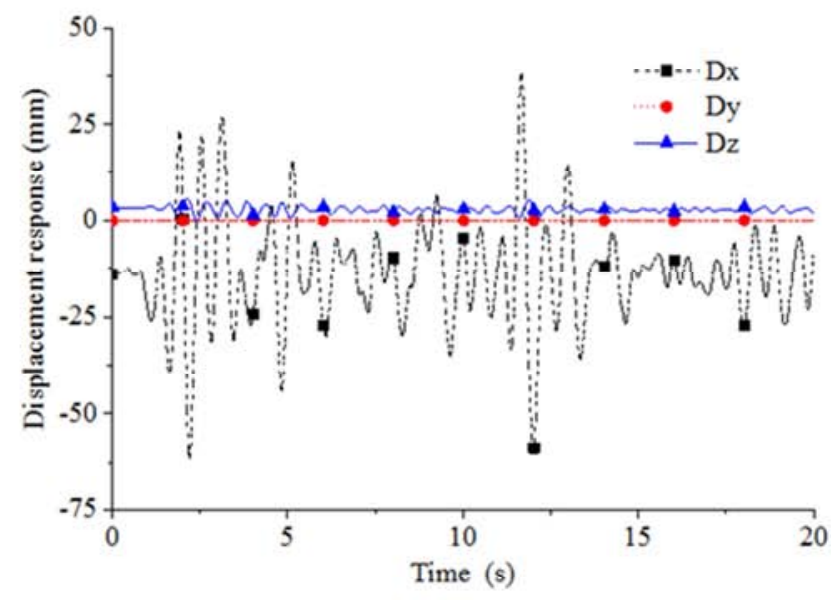

(e) $\mathrm{P} 5$

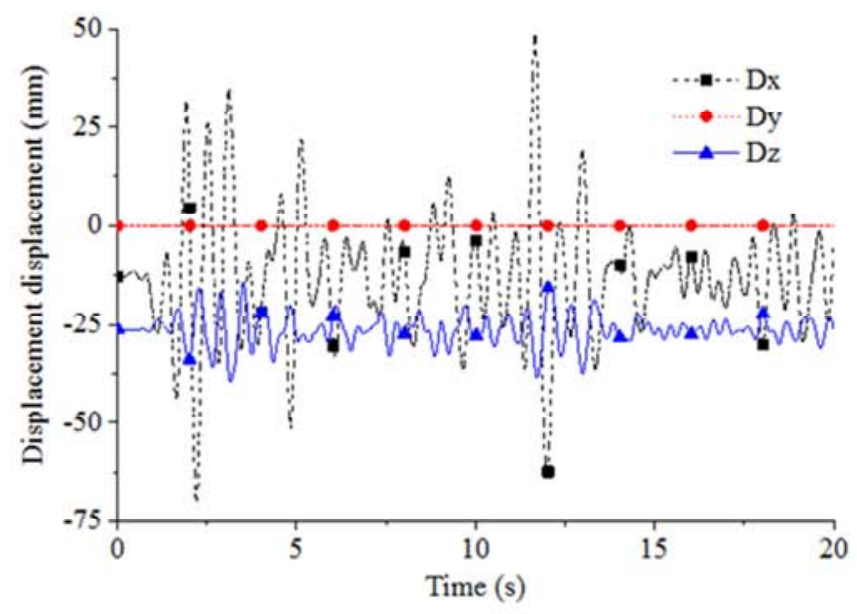

(b) P2

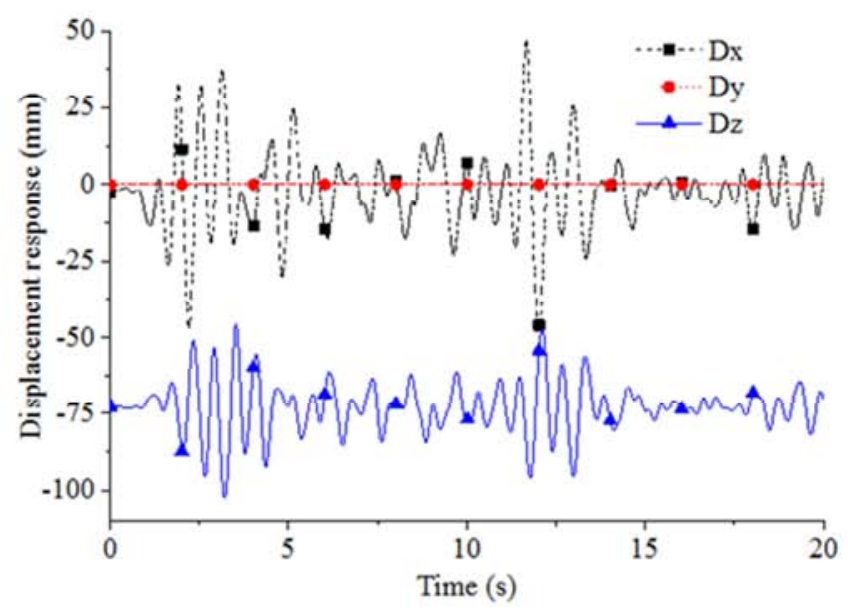

(d) P4

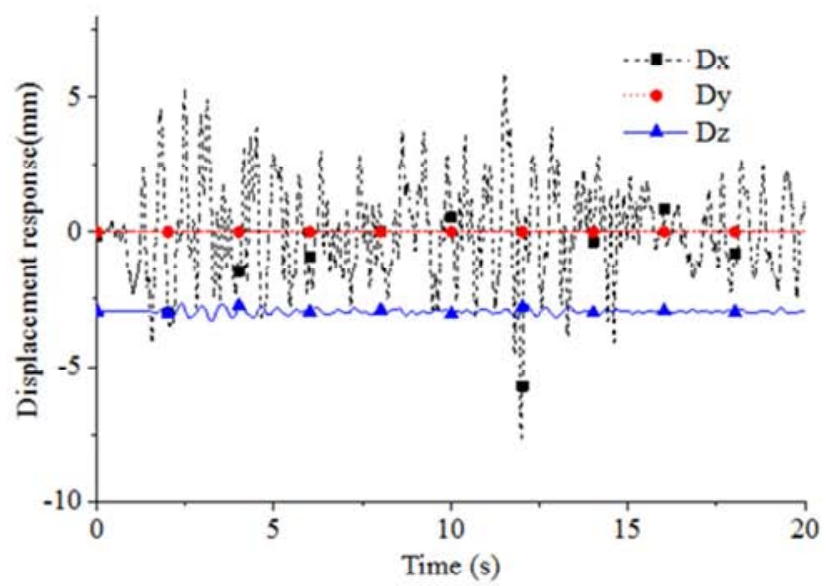

(f) P6

Figure 8. Displacement response results of each control point under working condition 2. 


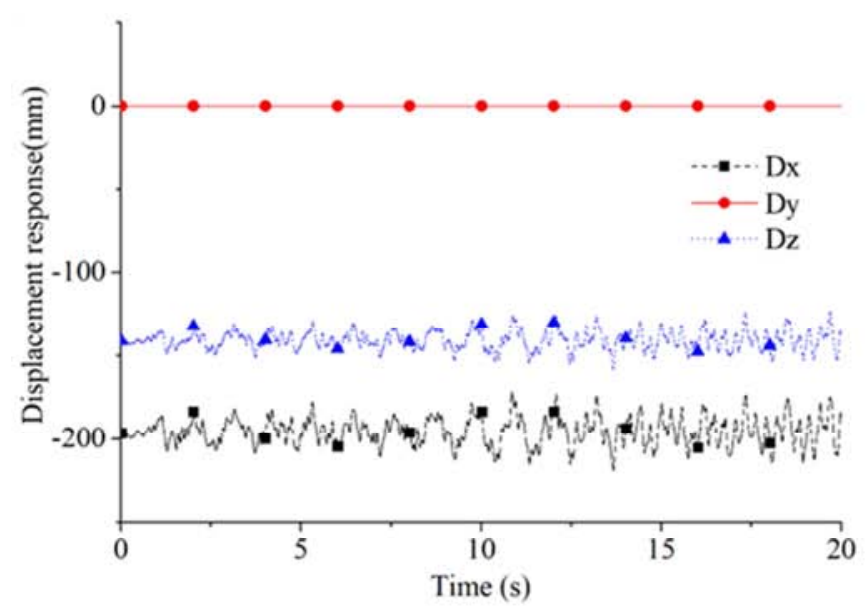

(a) P1

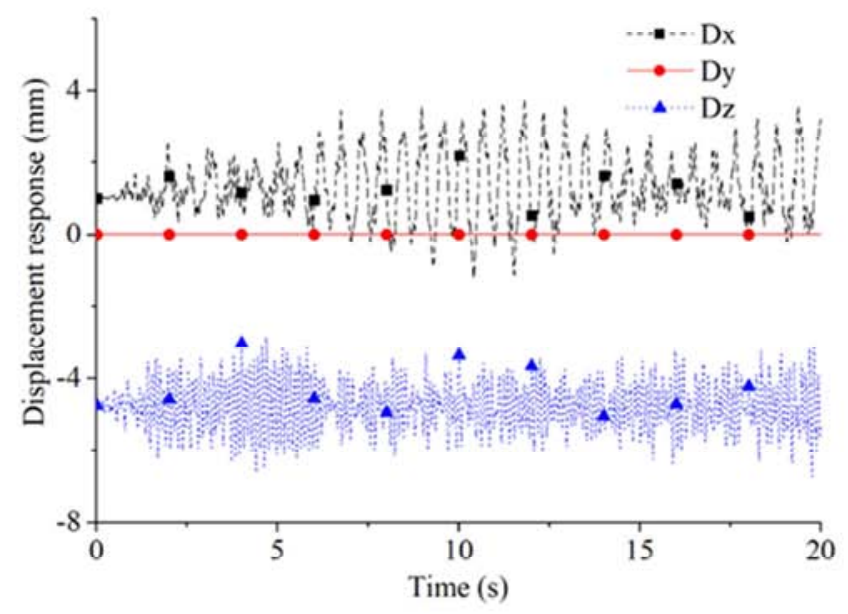

(c) P3

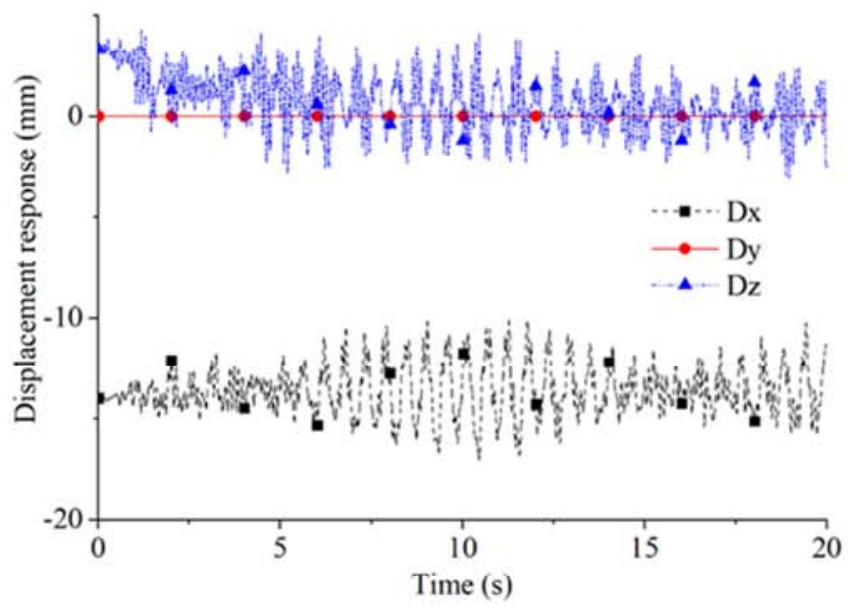

(e) P5

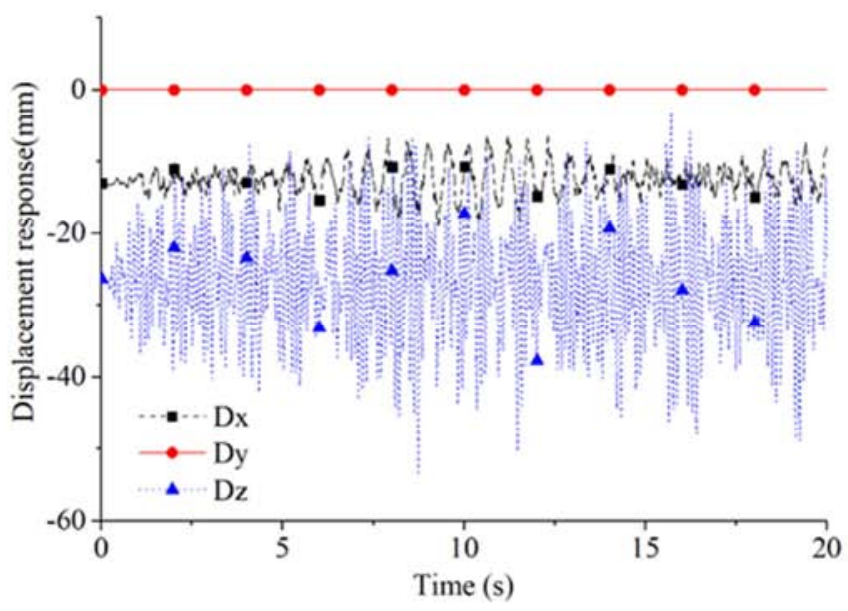

(b) P2

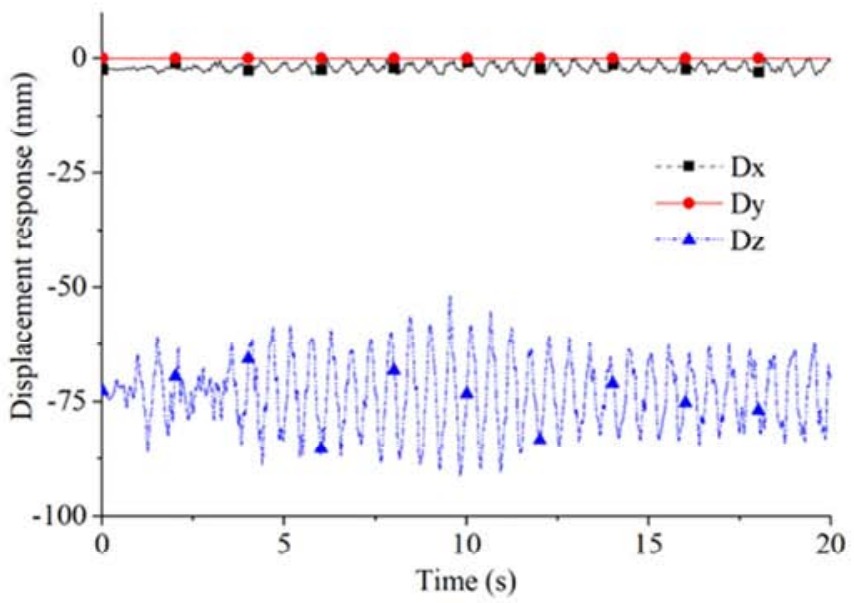

(d) P4

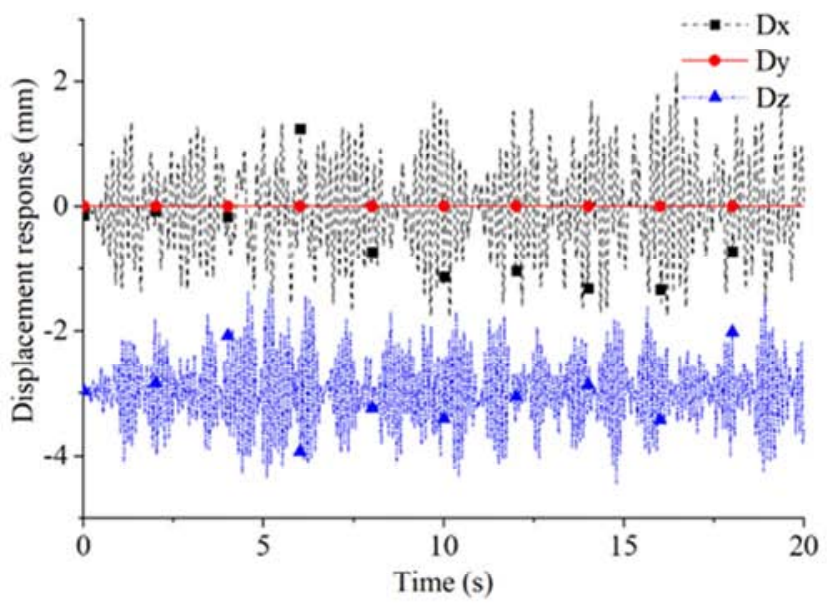

(f) P6

Figure 9. Displacement response results of each control point under working condition 3. 


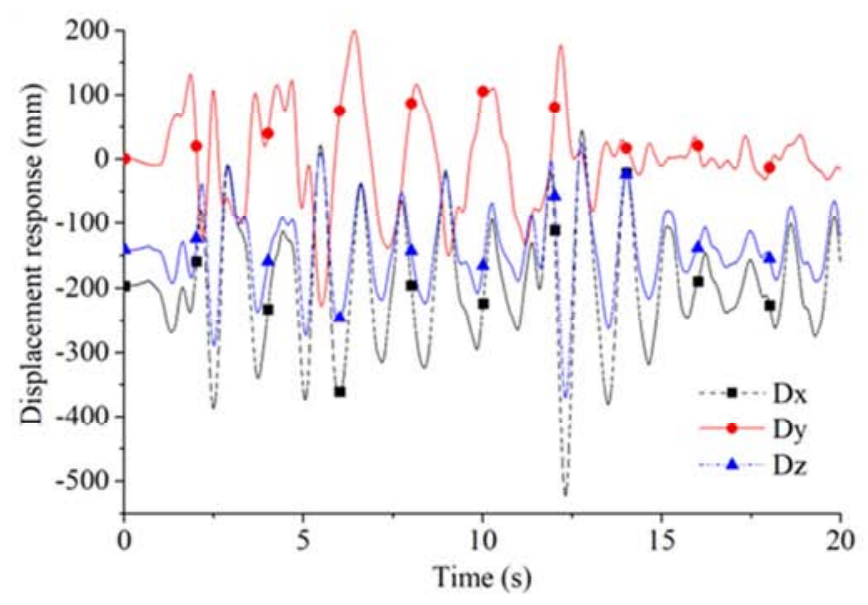

(a) P1

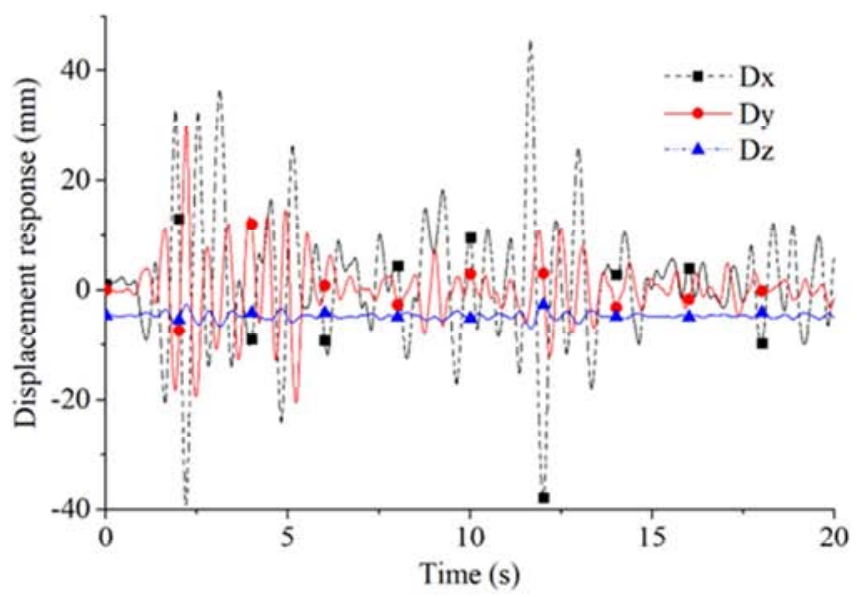

(c) P3

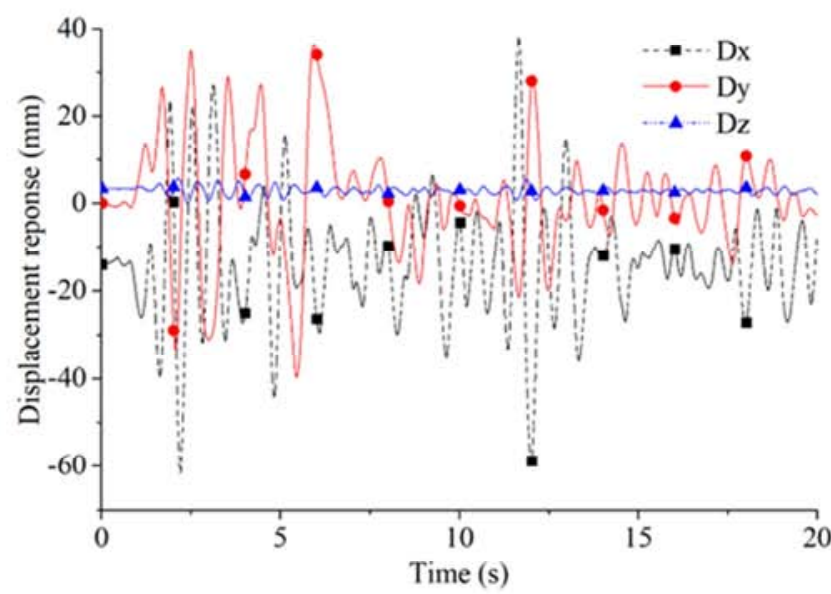

(e) P5

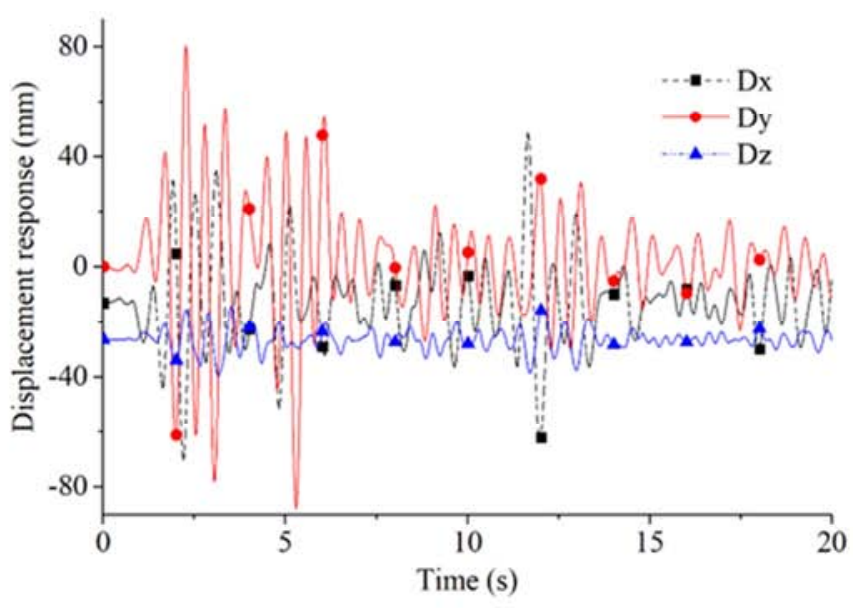

(b) P2

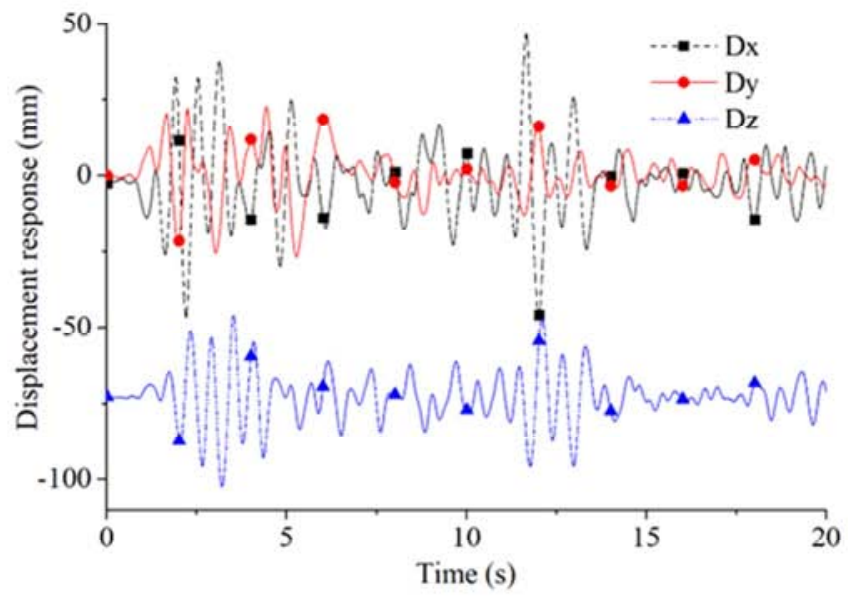

(d) P4

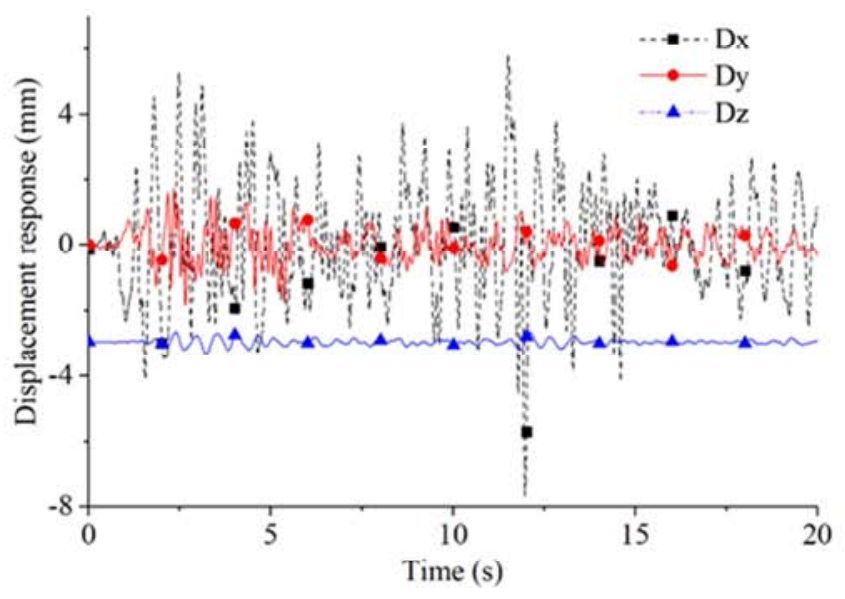

(f) P6

Figure 10. Displacement response results of each control point under working condition 4.

Analysis of the above figures reveals the following:

1) A comparative analysis of working conditions 4 and 5 shows that the seismic response time-history curves at the same control point under two working conditions are basically the same in terms of shape and trend in all directions, except for small differences in amplitude. Fluctuations occur in the transverse direction and that along the bridge at each control point.

2) Under a simultaneous input of seismic waves in three directions (working condition 5), fluctuations in the 
transverse direction and that along the bridge are observed. Compared with the displacement response results of working condition 4 , that of working condition 5 shows that the maximum amplitude of vertical fluctuations at the top of the main tower (P1) and the mid-span of the 2\# span (P4) are 12.32 and $3.22 \mathrm{~s}$, and the maximum amplitude fluctuations are only $0.96 \%$ and $3.16 \%$, respectively. Furthermore, the vertical fluctuations of the structure are mainly caused by structural deformation, whereas the vertical seismic action has a minimal effect on the structure under the

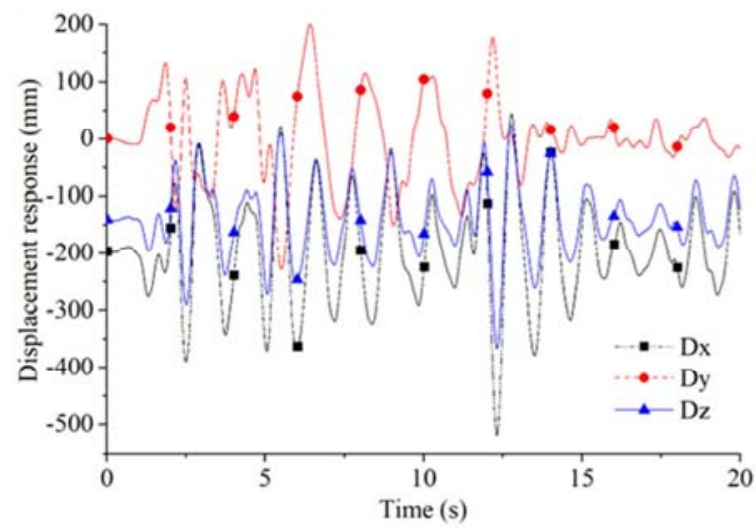

(a) P1

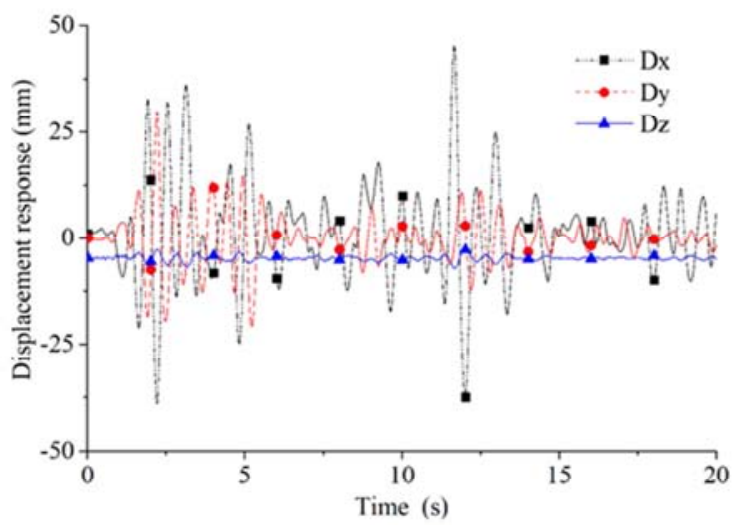

(c) P3

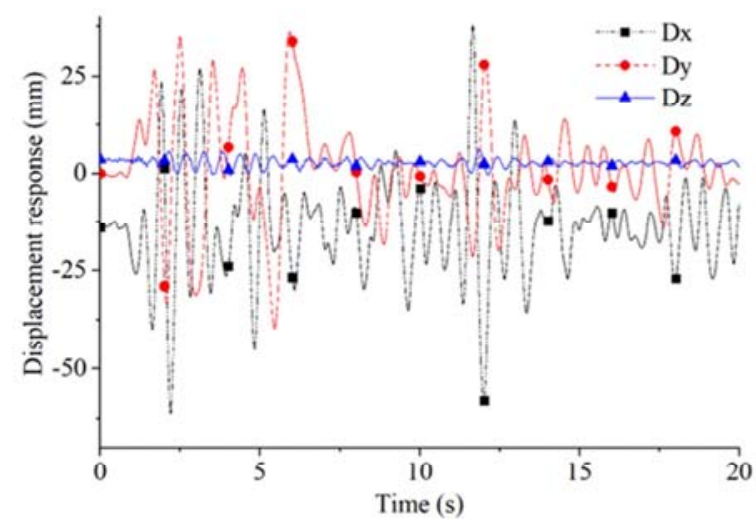

(e) P5 action of multidimensional earthquakes.

3) Under normal circumstances, the cable tower of ordinary cable-stayed bridges is set up vertically and has a relatively great vertical stiffness. The vertical seismic response at the top of the tower is similar to that at the bottom of the tower. The cable tower of the bridge is set up obliquely, thus reducing the vertical stiffness of the tower. The vertical time-history response amplitude at the top of the main tower (P1) is much larger than that at the top of the main pier (P3); such condition is unfavorable for the seismic analysis of the bridge.

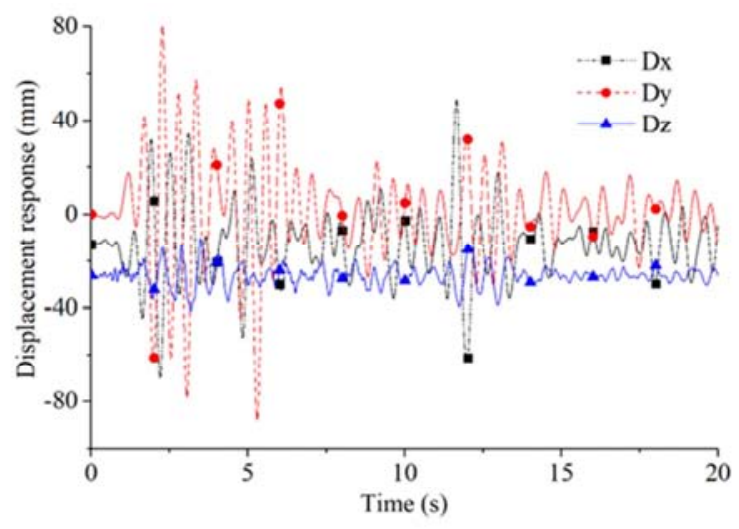

(b) P2

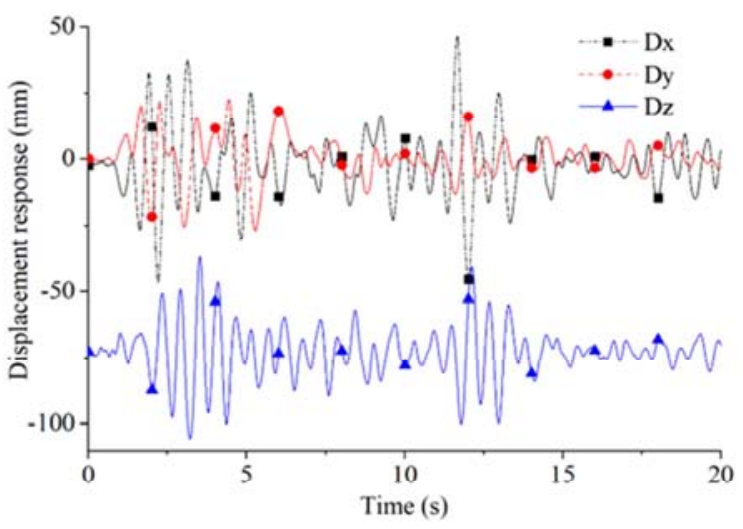

(d) P4

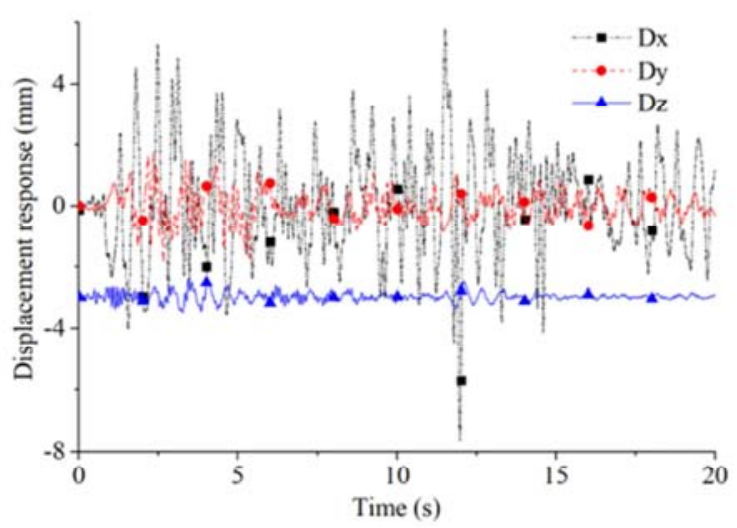

(f) P6

Figure 11. Displacement response results of each control point under working condition 5. 


\subsection{Comparative Analysis of the Time-history Response to One-dimensional and Multidimensional Earthquakes}

The response internal forces of the main stress positions of the bridge tower, arch rib, and main girder under the five earthquake load conditions are compared and analyzed. The maximum internal force value is shown in Table 5.

A summary table of the maximum values of internal force at key positions of the bridge structure under different earthquake loading conditions is shown below.

Table 5. Axial force, shear force unit: $k N$, bending moment unit: $k N$. m.

\begin{tabular}{|c|c|c|c|c|c|c|}
\hline $\begin{array}{l}\text { Component } \\
\text { name }\end{array}$ & Calculation term (location) & $\begin{array}{l}\text { Working } \\
\text { condition } 1\end{array}$ & $\begin{array}{l}\text { Working } \\
\text { condition } 2\end{array}$ & $\begin{array}{l}\text { Working } \\
\text { condition } 3\end{array}$ & $\begin{array}{l}\text { Working } \\
\text { condition } 4\end{array}$ & $\begin{array}{l}\text { Working } \\
\text { condition } 5\end{array}$ \\
\hline \multirow{3}{*}{ Cable power } & Axial force (bottom) & -74856.9 & -86003.3 & -93618.2 & -86412.5 & -87624.3 \\
\hline & Shearing force (bottom) & -17773.8 & -14241.1 & 20087.7 & -17792.9 & -17803.3 \\
\hline & Bending moment (bottom) & -92050.1 & -332451.2 & -195129.7 & -340563.9 & -342664.5 \\
\hline \multirow{3}{*}{ Arch rib } & Axial force (Near 1\# arch foot of the pier) & -45948.1 & -55222.6 & -53046.4 & -55264.6 & -56525.0 \\
\hline & Shearing force (Near $1 \#$ arch foot of the pier) & 4946.8 & 7020.2 & 7122.1 & 6933.6 & 7159.0 \\
\hline & Bending moment (1\# arch foot of the pier) & $\begin{array}{l}-21561.2 \text { (Arch } \\
\text { foot of the } 2 \# \text { deck) }\end{array}$ & 44098.7 & 47832.4 & 44146.2 & 45859.8 \\
\hline \multirow{2}{*}{ Wind bracing } & Axial force (tensile force) & 2542.2 & 1919.9 & 1942.6 & 2727.3 & 2761.4 \\
\hline & Axial force (pressure) & -1425.6 & -1092.8 & -1099.9 & -1494.0 & -1497.4 \\
\hline \multirow{2}{*}{ Main beam } & Positive bending moment & -9241.4 & -19856.9 & -34231.7 & -21317.3 & -21769.5 \\
\hline & Hogging moment & 58488.0 & 100347.0 & 97250.8 & 98651.0 & 98289.5 \\
\hline
\end{tabular}

Analysis of the table reveals the following:

1) A comparison of the maximum values of internal force calculated in each component under five working conditions shows that the values are basically under the same magnitude. This result indicates that the effect of one-dimensional and multidimensional earthquakes on the bridge structure should be paid the same degree of attention when performing a seismic analysis of cable-stayed arch bridges. A comparison of the internal force values of each group under horizontal, vertical, and three-directional earthquake actions shows that the difference of internal force values in the same group is relatively small. This result illustrates that the effects of horizontal and vertical earthquakes should be considered in the design of large-span bridges, especially those with complex structural systems.

2) The axial force and shearing force values at the bottom of the cable tower are the largest under working condition 3 but reduced under working condition 5 . This result is due to the fact that the inertial force generated by the superstructure mass under the vertical load is evident because the cable tower is a vertical columnar structure. However, under the three-dimensional seismic load, the bending moment produced by the horizontal direction is the eccentric pressure generated by the tower, which offsets part of the axial force under the vertical action. Furthermore, the effect of vertical seismic action cannot be ignored in the design of cable-stayed arch bridges, and the constant load effect should be considered.

3) Under the five earthquake loading conditions, the maximum and minimum values of each internal force of the arch rib appear at the position of the arch foot, which is consistent with the general law of earthquake response of the steel-tube arch bridge. Under the earthquake load of the transverse bridge, the maximum bending moment value occurs at the arch foot of the $2 \#$ abutment because the out-of-plane rigidity of the bridge is relatively small, and the deformation of the arch rib in the transverse direction is great only under transverse earthquakes. Attention should be focused on strengthening the antiseismic measures of the arch foot at such site.

4) When the Rayleigh damping of the structure is used in the model calculation, the amplitude of the time-history curve at each control point under the action of one-dimensional and multidimensional earthquakes decreases in varying degrees. For example, an evident amplitude attenuation can be found in P1 and P4 in three directions and in $\mathrm{P} 2$ in the horizontal direction. The more evident the attenuation, the more sensitive the response of the control point to the earthquake.

5) A comparative analysis on the axial force of the transverse wind bracing of the arch rib shows that under the earthquake load of various working conditions, tension and pressure occur in the wind bracing, and the maximum value of the pressure cannot be ignored in comparison with the maximum value of the tension. Moreover, the deformation of wind bracing is evident. Considering the principle of the energy dissipation of plastic hinges, wind bracing is important in maintaining the stability of arch ribs during earthquakes and ensuring the slight damage of arch ribs.

\section{Conclusions}

The strength, stiffness, and stability check calculations and the effect of earthquakes should be considered in the design of cable-stayed arch bridges with collaborative systems. In this study, a cable-stayed arch bridge is modeled and analyzed using Midas Civil finite element analysis software. Analyses of the dynamic characteristics and structural response of the structure under seismic action are also conducted. The following conclusions are drawn:

1. The low fundamental frequency of bridges with the cooperative systems indicates that the overall rigidity of 
the structure is small, the spectrum is scattered, the low-order frequencies are dense, and the changes are uniform. The overall mass space distribution of the structure is similar to that of the cable-stayed bridge without backstays, indicating that the dynamic characteristics of the bridge are similar to those of the cable-stayed bridge without backstays. The seismic analysis of the bridge focuses on the analysis of the cable tower, main span, main beam, and arch ribs. The ratio of in-plane fundamental frequency to out-of-plane fundamental frequency is $1.8124 / 0.5038$, indicating that in-plane stiffness is considerably greater than out-of-plane stiffness. This result illustrates that the transverse stability problem of bridges is prominent and should be the focus of antiearthquake fortification.

2. The time-history response analysis reveals that the structural displacement response value under the transverse bridge action is the largest under the earthquake in the single direction. Compared with the horizontal and three-directional earthquake actions, fluctuations occur in the transverse direction and that along the bridge at each control point. The analysis of the control point at the top of the cable tower indicates that the inclined cable tower of this bridge is not conducive to the earthquake resistance of the structure in comparison with the vertical cable tower. The results of the analysis of the internal force response of the structure show that the bridge structural system is complicated, and the influence of horizontal and vertical earthquake actions should be considered in antiearthquake designs.

\section{Author Contributions}

Conceptualization, S. W.

\section{Funding}

This research was funded by Harbin Talent Project (Grand No. RC2017QN012019).

\section{Conflicts of Interest}

The authors declare that they have no competing interests.

\section{References}

[1] Xing-Wang Sheng, Wei-Qi Zheng, Zhi-Hui Zhu, Yong-Ping Qin, Jian-Guang Guo. Full-scale fatigue test of unit-plate ballastless track laid on long-span cable-stayed bridge [J]. Construction and Building Materials, 2020, 247.

[2] Chuang Cui, You-Lin Xu, Qing-Hua Zhang, Feng-Yang Wang Vehicle-induced fatigue damage prognosis of orthotropic steel decks of cable-stayed bridges [J]. Engineering Structures, 2020, 212 .

[3] As useless as the russky island bridge [J]. Current Digest of the Russian Press, 2012, 64 (27).
[4] Chao Zhao, Yunlong Xiong, Xingu Zhong, Zheng Shi, Sheng Yang. A two-phase modeling strategy for analyzing the failure process of masonry arches [J]. Engineering Structures, 2020, 212.

[5] Huabing Fang, Ou Li. Load test of Chongqing Chaotianmen Yangtze River Bridge [J]. Railway Engineering, 2015 (02): 12-15.

[6] Bruno D, Greco F, Lonetti P. A Parametric Study on the Dynamic Behavior of Combined Cable-Stayed and Suspension Bridges under Moving Loads [J]. International Journal for Computational Methods in Engineering Science and Mechanics, 2009, 10 (4): 243-258.

[7] Klein P, Yamout M. Cable-Stayed Arch Bridge, Putrajaya, Kuala Lumpur, Malaysia [J]. Structural Engineering International, 2003, 13 (3): 196-199.

[8] ZHAO Yue-yu, PENG He-xing, WANG Lian-hua. Stochastic Response of Cable-stayed Arch Bridge under Multi-component Seismic Excitation [J]. Journal of Highway \& Transportation Research \& Development, 2008, 2, 25.

[9] Lu W, Zhou D, Chen Z. Practical Calculation of Cable-Stayed Arch Bridge Lateral Stability [J]. Applied Mechanics and Materials, 2014, 587-589: 1586-1592.

[10] Wang W, Ph. D, Ph. D, et al. Dynamic Analysis of a Cable-Stayed Concrete-Filled Steel Tube Arch Bridge under Vehicle Loading [J]. Journal of Bridge Engineering, 2014, 20 (5): 04014082.

[11] Li Y, Wang J L, Ge S S. Optimum Calculation Method for Cable Force of Concrete-Filled Steel Tube Arch Bridge in Inclined Cable-Stayed Construction [J]. Journal of Highway and Transportation Research and Development (English Edition), 2017, 11 (1): 42-48.

[12] Dong X, Bin C, Lei L. Tensioning Process of Sanhao Arch Pylon Cable-Stayed Bridge [J]. Iabse Symposium Report, 2009, 96 (11): 49-56.

[13] Lee B H K, Gong L, Wong Y S. Analysis and computation of nonlnear dynamic response of a two-degree-of-freedom system and its application in aeroelasticity [J]. Journal of Fluids \& Structures, 1997, 11 (3): 225-246.

[14] Zhixiong Li, Z. Peng. Nonlinear dynamic response of a multi-degree of freedom gear system dynamic model coupled with tooth surface characters: a case study on coal cutters [J]. nonlinear dynamics, 2015, 84 (1): 1-16.

[15] Crampin S. Seismic-wave propagation through a cracked solid: polarization as a possible dilatancy diagnostic [J]. Geophysical Journal of the Royal Astronomical Society, 1978, 53 (3): 467-496.

[16] Dimitri Komatitsch, J. Tromp. Spectral-Element Simulations of Global Seismic Wave Propagation-II. 3-D Models, Oceans, Rotation, and Self-Gravitation [J]. Geophysical Journal of the Royal Astronomical Society, 2002, 150 (1): 303-318.

[17] Komatitsch D, Tromp J. A perfectly matched layer absorbing boundary condition for the second-order seismic wave equation [J]. Geophysical Journal of the Royal Astronomical Society, 2003, 154 (1): 146-153.

[18] Komatitsch D, Martin R. An unsplit convolutional perfectly matched layer improved at grazing incidence for the seismic wave equation [J]. Geophysics, 2007, 72 (5): SM155-SM167. 